\title{
Anthropogenic factors affecting wildlife species status outcomes: why the fixation on pesticides?
}

\author{
Richard A. Brain ${ }^{1}$ (D) Julie C. Anderson ${ }^{2}$ \\ Received: 29 December 2019 / Accepted: 22 April 2020 \\ (C) The Author(s) 2020
}

\begin{abstract}
Most Americans are at least three generations removed from the farm, thereby at least three generations removed from the reality of where their food comes from. Not surprisingly, there are many misconceptions about modern food production, including the potential collateral environmental damage attributed to agriculture, particularly the application of pesticides. However, the implication of conventional agriculture in the broader narrative of wildlife species status outcomes (SSOs) lacks context and relativity. Since the dawn of civilization, humans have had a profound impact on their environment. Originating as hunter-gatherer societies, our ancient ancestors initially exploited anything that could be consumed or brought to bear. With the advent of the "first proto-farmers," humans began manipulating their environments to maximize available resources. Urban centers propagated and flourished proximal to agricultural origins, where modern societies have been built primarily on an abundance of food. As societies "developed," and continue to develop, an inevitable economic transition occurs from agriculture to industry/service predominance, culminating in a corresponding shift in land use. Developed countries have typically experienced maximal expansion of the agricultural frontier, where farmland is now steadily eroding by a proverbial flood of urban development. In contrast, in developing countries, this shift in economic development has not yet fully manifested and the agricultural footprint continues to expand at the expense of native habitats. Thus, the relative influence of "agriculture" on SSOs, in terms of land use, is primarily dependent on economic developmental status, which can be, at least in part, ameliorated via technology by increasing yield from existing land. Moreover, in addition to the land use challenge, there are multiple other factors affecting wildlife SSOs, including a figurative plague of invasive species, a literal plague of disease, a barrage of buildings, bumpers, grilles, and windshields to collide with, light pollution to confuse cues with, poachers to contend with, and even more complicated factors such as climate change. Being an easy target does not mean pesticides are the right target, and this fixation can potentially detract from public awareness regarding the primary drivers affecting SSOs as well as the opportunity to proactively address them. So, relatively speaking, how do these other factors compare to "pesticides" in terms of driving SSOs? Moreover, why is the popular media so fixated on the pesticide narrative? Based on the available evidence, this manuscript attempts to address these questions from a holistic and relative perspective within the context of land use change, economic development, population growth, and associated implications of global connectivity and commerce.
\end{abstract}

Keywords Pesticides $\cdot$ Anthropogenic factors $\cdot$ Wildlife $\cdot$ Species status outcomes

\section{Introduction}

Since the appearance of the first hominids in Africa some 4,000,000 years ago, there has, unwittingly, been a Darwinian

Responsible editor: Philippe Garrigues

Richard A. Brain

richard.brain@syngenta.com

1 Syngenta Crop Protection LLC, Greensboro, NC, USA

2 Environmental Consultant, R3N0T8, Winnipeg, Canada (i.e., evolutionary) pandemic on earth. Progressively evolving from Australopithecus spp., into hunter-gatherer societies and ultimately culminating in the dawn of humanity (i.e., Homo sapiens) $\sim 300,000$ years ago, humans have had a profound impact on their environment. Hunting for subsistence, our ancestors exploited wildlife for food and resources, driving some species to the point of extinction, such as the wooly mammoth. This nomadic social construct prescribed taking and consuming whatever the environment had available; however, due to resource scarcity and/or depletion, hunter-gatherers progressively began to manipulate their environments to increase the amount of food available (Tudge 1998). In fact, humans first began 
managing their environment (via horticulture and coercing prey to behave more amenably) $\sim 40,000$ years ago in the Paleolithic period as "proto-farmers" in Mesopotamia, the Indus Valley, China, and the Americas (Tudge 1998; Tauger 2011). The Neolithic farming "revolution" (cultivating crops and domesticating livestock) is largely ascribed to the Fertile Crescent 10,000 years ago (Tudge 1998; Tauger 2011), from which the contemporary concept of modern agriculture is believed to have originated.

Agriculture is a fundamental prerequisite for the formation of urban centers (Satterthwaite et al. 2010; Imhoff et al. 2004; Rees 1992; Tauger 2011) and, not surprisingly, the first cities (e.g., Jericho) began to appear in Mesopotamia proximal to the origins of agrarian food production. As civilization expanded following the farming revolution, trade routes were established in order to transport goods from areas of production to areas of commerce. Examples of this include the "Silk Road" linking China and the Roman Empire in the first century BCE (Hansen 2012) and the maritime "Spice Routes" (Sidebotham 2011) connecting the East and West in the fifteenth to seventeenth centuries. This resultant global connectivity has facilitated human migration and trade throughout the world; however, disease and invasive species have been spread concomitantly.

As populations increased so to, necessarily, did the resources required to support them. Agricultural production has increased accordingly throughout history to facilitate the population growth of humanity. Unfortunately, the larger the population, the greater the required land allocation to agriculture. With a current global population of $\sim 7$ billion people, $37 \%$ of the land surface on earth is allocated to agriculture ( $12 \%$ crops and $\sim 25 \%$ livestock) (FAO 2009, 2019a). Present global urban land cover is projected to increase by 120 million hectares by 2030 (Seto et al. 2012) at the expense of farmland and native habitat, and crude estimates indicate that there are already $\sim 64$ million $\mathrm{km}$ (40 million miles) of roads (CIA World Fact Book 2019) with over a billion vehicles (Davis and Boundy 2019) worldwide.

Given the historical overexploitation of species for subsistence, the dynamic change in land use to agriculture and urbanization, the transmission of disease and introduction of invasive species, as well as the nexus of modern transportation infrastructure and other challenges including climate change, the potential implications of civilization for wildlife appear somewhat ominous. In fact, it has been estimated that humans represent just $\sim 0.01 \%$ of the biomass on earth $(\sim 3 \%$ of the total animal biomass) but are responsible for an approximate $85 \%$ reduction in wild mammal biomass (Bar-On et al. 2018). However, people need to eat and wildlife needs to be preserved, and in order to realize the synchronous manifestation of these seemingly divergent objectives, humanity must extract maximal efficiency from the arable land currently available for production agriculture. Attainment of this objective requires informed public discourse, which is predicated on context and reality rather than sensationalism and popular culture (Brain and Anderson 2019).

Among the milieu of potential SSO drivers, pesticides have become an easy target - they have a contentious origin (Carson 1962), plausible biological relevance (i.e., fidelity of physiological processes shared between target and non-target species relevant to pesticide modes of action; Fukuto 1990, BCPC 2018), and an easily exploited legal construct in the USA (e.g., citizen suit provisions [see Clean Water Act (CWA): USEPA 2002a; Endangered Species Act (ESA): USFWS 1973). When they were first introduced, organochlorine insecticides were considered a marvel of modern chemistry. DDT was even referred to as an "excellent powder" by Winston Churchill (Roberts et al. 2016). However, despite the countless lives saved from mosquito-borne malaria, the environmental impacts had not been appreciably considered or assessed. Two decades later, DDT was given a new, and decidedly more dubious, catchphrase: "elixir of death" (Carson 1962). Quite a stark, but environmentally accurate, contrast, which spurred establishment of the US Environmental Protection Agency (USEPA) in 1970 and passing of the Federal Environmental Pesticide Control Act in 1972 and Endangered Species Act in 1973.

Yet, despite establishment of necessary regulation and oversight, anticipation of the next Silent Spring (Carson 1962) seems omnipresent. If such an improbable recurrence manifested, it would represent no less than the biggest example of regulatory failure and corporate malfeasance since Operation Berkshire (Francey and Chapman 2000). The required regulation and oversight currently, and necessarily, in place for pesticides serve to protect against such an event, but the potential for this type of scenario is increasingly propagated in the popular media (e.g., Goulson 2018; Isenring 2010). Notwithstanding, the authors acknowledge that the effectiveness of regulatory paradigms vary with respect to regional economic developmental status and that illicit pesticide use is difficult to mitigate or characterize. There is no denying that pesticides present inherent human and environmental risks; albeit, under the resultant regulatory framework (in more developed countries), rigorously and conservatively evaluated risks.

Although the associated implications of land use change, invasive species, disease, vehicle collisions, poaching, and other factors (e.g., climate change) are well-documented, agriculture-and particularly synthetic pesticides - is most often implicated as the predominant contemporary factor influencing wildlife species status outcomes (SSOs). Pesticides have become an easy target for litigious opportunism, and conveniently featured in the narrative of global species decline; though, we argue that this implication lacks context and empirical evidence. So, relatively speaking, to what degree do pesticides 
contribute to wildlife species status outcomes in the US compared to other potential factors?

This manuscript attempts to address this question, focusing on vertebrates (specifically, mammals), by exploring the following areas: (1) historical land use change within the USA versus developing countries (as defined by the United Nations; UN 2019) in the context of economic developmental cycles, (2) identifying and characterizing other potential contributors to SSOs, including invasive species, disease, light pollution, and vehicular collisions, and (3) comparing the toxicity of current use pesticides with previous generations of chemistry. To do so, the authors undertook the following: (1) exploration of historical land use data for the USA (as described in Brain and Anderson 2019) and developing countries (Brazil and China as model countries) in order to characterize and compare the implications of economic developmental stage, (2) review of literature sources evaluating the impacts of invasive species and other potential factors on SSOs, and (3) comparison of the toxicity of currently registered insecticides relative to previous generations using toxicity and incident data from model mammalian species (i.e., rat, as available). The authors acknowledge that this review was not an exhaustive exercise, but efforts were made to ground the analysis in data where opportunities facilitated.

In the "Potential drivers of wildlife declines" section, individual drivers of wildlife population declines are examined to characterize relative contributions to loss of species or individuals. Geographically, the primary focus of this analysis was the USA; however, other countries/regions are utilized for comparison and context where appropriate and necessary. For example, evaluation of the comparative influence of economic developmental status with respect to land use and SSOs necessitates geographically diverse comparison and some statistics are only defined globally (not regionally or by country). The "Differences in drivers and outcomes in developed versus developing regions - contrasting the USA with China and Brazil" section compares the drivers and outcomes as they pertain to developed and developing regions, with the USA, Brazil, and China serving as examples for different stages of economic development. Finally, the "Discussion and conclusions" section attempts to distill the information from the previous sections and offer more general conclusions regarding SSOs and the role of agriculture in context.

\section{Trends in wildlife populations}

Over the past 40 years, there has been an estimated 50 to $60 \%$ average decline in wild animal populations (Stein et al. 2018; WWF 2018). According to the World Wildlife Fund (WWF 2018), major contributors to global species decline include habitat loss and degradation, overexploitation, climate change, pollution, and invasive species. Declines have been particularly pronounced in South and Central America, though mammals across the globe have faced extinction rates 100 to 1000 times background levels (WWF 2018). Bar-On et al. (2018) estimated the distribution of biomass on earth and determined that animals comprise approximately 2 of 550 Gigatonnes of carbon, of which wild mammals amount to less than $0.5 \%$ of total animal biomass. The authors suggested that over geologic time, humans have contributed to the loss of about half of the largest land mammals and an overall shift from wild animals to livestock species (Bar-On et al. 2018). Given the challenge of counting all wildlife species and individuals, exact estimates may vary in terms of absolute change or current populations, but there is consensus that wildlife losses have been dramatic and driven primarily by humans.

In the USA, trends vary by geographic region and taxa, but are generally consistent with observed global declines (Flather et al. 2013). Biodiversity losses over the course of industrial development have been most pronounced in California, the Midwest, the South, and the Northeast (Noss et al. 1995). Recent reports suggest that a third of wildlife species in the USA are considered vulnerable, with another $20 \%$ considered imperiled and at high risk of extinction (Stein et al. 2018; Flather et al. 2013). As of 2010, at least 80 species of mammals were considered threatened or endangered (Flather et al. 2013). Of critically endangered ecosystems (i.e., >98\% decline), the greatest habitat losses have been in barrens, grassland, and savannah communities (Noss et al. 1995). These losses have been both quantitative (e.g., conversion of habitat to urban development) and qualitative (i.e., degradation or change in ecosystem function, structure, and/or composition) (Noss et al. 1995).

Myers et al. (2000) reported that globally, 25 biodiversity hotspots (representing only $1.4 \%$ of total land area) contain 9,645 vertebrate species. Overall, in Mediterranean-type ecosystems (MTE, floral biodiversity hot spots), agricultural and urban land use areas increased $13 \%$ and 1\%, respectively, between 1990 and 2000 (Underwood et al. 2009). One of these MTE hotspots is located in the USA - the California Floristic Province - and is home to $\sim 145$ species of mammals, including 30 species endemic to only California (Myers et al. 2000). This region has experienced considerable population growth and an increase in urbanized area since 1940 (Eaton-Gonzalez and Mellink 2015). Between 1993 and 2011, the area of land comprised by urban developments in the Californian section of the Tijuana River Watershed (a watershed of the California Floristic Province) increased from 3.51 to $11.34 \%$, a change of 20,170 ha (Eaton-Gonzalez and Mellink 2015). Curiously, Gaston (2005) reported that evidence from previous studies indicated a positive correlation between regional species richness and human density, which is not necessarily an intuitive finding. However, upon reflection, the concept that biodiversity hotspots are energy and resource-rich regions for supporting animals (and people) 
would seem reasonable, up to a finite capacity. Consequently, these hotspots then become even more important for conservation and more susceptible to overexploitation (Gaston 2005).

\section{The challenge of feeding the world}

According to Gaston (2005), "The most important agent of change in...much of biodiversity at present is ultimately the size, growth, and resource demands of the human population." With increasing population, as well as wealth-driven per capita consumption, there is an increasing demand for fuel, food, and fiber (Thompson 2007; WWF 2018). The world population is projected to reach 9.8 billion in 2050, and 11.2 billion in 2100, placing an additional $30 \%$ demand for resources by the end of the century (UN 2017). Harvesting of fish and wildlife supports the livelihood of around $15 \%$ of the global population currently, providing protein for over a billion of the world's poorest people (Brashares et al. 2014). With advances in agricultural technology, food production has actually kept pace with, and even exceeded, demands to date. As such, global hunger is more tightly linked to poverty and lack of available food in place, presenting a challenge to grow food where people are (Tscharntke et al. 2012), as well as accounting for future additional mouths to feed. Conservation is much more complicated in the context of localized scarcity, where financial incentives encourage overexploitation of wildlife and land resources, and ecological concerns are of lower priority than immediate human sufferings (including starvation, human trafficking, and child labor) (Brashares et al. 2014).

Despite this, it is becoming more widely recognized that biodiversity is crucial to sustaining healthy and productive agroecosystems (WWF 2018), such that "meeting food production needs and protecting biodiversity are increasingly part of the same agenda" (Smith et al. 2012).

\section{Potential drivers of wildlife declines}

\section{Agricultural drivers}

\section{Habitat loss/degradation}

Economic development and land use change Habitat loss is primarily cited as the dominant contemporary factor threatening species viability, particularly land conversion to agriculture (WWF 2018). However, the process of land conversion is dynamic, varying temporally relative to a given country's economic developmental stage along the continuum between agrarian and industry/service-based economies. As described by Wolfersberger et al. (2015), citing Rudel et al. (2005), "Once a certain level of income per capita and of capital stock is reached, the country is able to switch from an agriculturebased economy to an industry-based economy. Farmers leave their lands for urban jobs with higher wages. Agricultural production becomes more intensive and some previously abandoned lands revert to forest." Thus, once the agricultural footprint plateaus, socio-economic and political forces shift land conversion from agriculture to urbanization (LeBlois et al. 2017; Wolfersberger et al. 2015).

Implications of land use change In developing countries, land is often being consumed for the purposes of agricultural expansion (OECD 2018; LeBlois et al. 2017), whereas in developed countries, agricultural land use has typically reached a plateau or even contracted, albeit while production is increasing (USDA ERS 2018; Statistics Canada 2019; Maes et al. 2015). In the USA, agricultural expansion is no longer a significant driver since the land allocation to farming has already peaked and is now in decline, while urban land use is increasing (USDA ERS 2018). In contrast, many regions currently classified as "developing" (UN 2019) in the context of economic developmental progression, including the Tropical Andes and Brazil's Cerrado, are converting native habitats to agricultural lands (Killeen et al. 2007; OECD 2018). Tragically, these regions are also coincidentally recognized as global biodiversity hotspots (Myers et al. 2000; OECD 2018). Not surprisingly, this spatiotemporal overlay between development and biodiversity creates an obvious conflict of interest with respect to conservation. Clearly, converting oases of biodiversity to production agriculture is not sustainable, but how do we mitigate against this economic development-based cycle in order to avoid further loss? Unfortunately, the answer is complex, involving a delicate interplay of social, political, and economic forces, both regionally and globally. Notwithstanding, production agriculture needs to be efficient to be sustainable and technology may well turn the tide of land conversion.

\section{Agrochemicals}

Relevance of pesticides to SSOs With the exception of rodenticides, mammals typically differ physiologically from target pest organisms (i.e., weeds, insects, fungi), though some fidelity of target receptor continuity does occur, particularly for highly conserved biological processes such as nervous system function (Fukuto 1990). However, even in such cases, there can be marked differences in sensitivity, particularly between invertebrates and vertebrates (see Table 1). Notwithstanding, some researchers have suggested that pesticide use is strongly correlated with bird and mammal species declines.

Gibbs et al. (2009) concluded that high losses of imperiled bird and mammal species in the Canadian prairies were associated with pesticide use, though it was not possible to delineate pesticide use from strongly collinear variables (e.g., 
Table 1 Mammalian toxicity (rat acute and chronic oral) and chemical property data for classes of pesticides in chronological order of introduction

\begin{tabular}{|c|c|c|c|c|c|c|c|c|c|}
\hline Class/compound & $\begin{array}{l}\text { Rat } \\
\text { acute } \\
\text { oral } \\
\mathrm{LD}_{50} \\
(\mathrm{mg} / \mathrm{kg} \\
\text { bw) }\end{array}$ & $\begin{array}{l}\text { Rat } \\
\text { chronic } \\
\text { NOAEL } \\
\text { (mg/kg } \\
\text { bw/day) }\end{array}$ & $\begin{array}{l}\text { Mammalian } \\
\text { acute oral } \\
\text { toxicity } \\
\text { rating }{ }^{\gamma}\end{array}$ & $\begin{array}{l}\text { Honey } \\
\text { bee acute } \\
\text { contact } \\
\mathrm{LD}_{50}(\mu \mathrm{g} \\
\text { a.i./bee) }\end{array}$ & $\begin{array}{l}\text { Honey } \\
\text { bee acute } \\
\text { oral } L_{50} \\
(\mu g \text { a.i./ } \\
\text { bee) }\end{array}$ & $\begin{array}{l}\text { Log } \\
K_{\text {ow }}\end{array}$ & $\begin{array}{l}\text { Aerobic } \\
\text { soil half- } \\
\text { life } \\
\text { (day) }\end{array}$ & $\begin{array}{l}\text { Max single } \\
\text { application } \\
\text { rate for } \\
\text { agriculture } \\
\text { (lb a.i./A) }\end{array}$ & Source(s) \\
\hline
\end{tabular}

Organochlorines (1940s to 1972)

\begin{tabular}{|c|c|c|c|c|c|c|c|c|c|}
\hline DDT & 113 & 25 & Category II & 7.12 & 5.08 & 7.48 & $\begin{array}{l}730 \text { to } \\
5475\end{array}$ & 1.2 to 12 & $\begin{array}{l}\text { WHO (1989); FAO (1967); } \\
\text { ASTDR (2002a); Atkins } \\
\text { et al. (1975); USEPA (2019) }\end{array}$ \\
\hline Aldrin & 39 & $<0.63$ & Category I & 0.353 & 0.239 & 6.50 & $\sim 53$ & 0.5 to 5 & $\begin{array}{l}\text { ATSDR (2002b); USEPA } \\
\text { (1986); Martin (1968); } \\
\text { USEPA (2003); Atkins et al. } \\
\text { (1975); Jones and Connell } \\
\text { (1954) }\end{array}$ \\
\hline Dieldrin & 37 & $<0.125$ & Category I & 0.139 & 0.269 & 6.20 & $\sim 913$ & 0.1 to 1.5 & $\begin{array}{l}\text { ATSDR (2002b); Brooks } \\
\text { (1974); Andersen and } \\
\text { Weihing (1959); USEPA } \\
\text { (2003); Atkins et al. (1975); } \\
\text { Jones and Connell (1954) }\end{array}$ \\
\hline Heptachlor & 40 & 3 & Category I & 0.562 & NA & 5.44 & $\begin{array}{c}730 \text { and } \\
5110\end{array}$ & 2.5 to 10 & $\begin{array}{l}\text { WHO (2006); ATSDR (1989); } \\
\text { USEPA (1960); Atkins et al. } \\
\text { (1975) }\end{array}$ \\
\hline Toxaphene & 80 & 46 & Category II & 50.4 & 39.81 & 6.64 & $\begin{array}{r}3650 \text { to } \\
5110\end{array}$ & 1.5 to 2 & $\begin{array}{l}\text { ATSDR (2014); Fingerling } \\
\text { et al. (1996); Andersen and } \\
\text { Weihing (1959); Atkins et al. } \\
\text { (1975); Jones and Connell } \\
\text { (1954) }\end{array}$ \\
\hline Mirex & 365 & 0.31 & Category II & 7.15 & NA & 5.28 & $>3650$ & $\begin{array}{r}0.001 \text { to } \\
0.004\end{array}$ & $\begin{array}{l}\text { ATSDR (2019); Atkins et al. } \\
\text { (1975) }\end{array}$ \\
\hline Chlordane & 137 & $<16$ & Category II & 5.23 & 1.122 & 5.54 & 2920 & 1.5 & $\begin{array}{l}\text { ATSDR (2018); Nash and } \\
\text { Woolson (1967); USEPA } \\
\text { (1969); Atkins et al. (1975) }\end{array}$ \\
\hline Lindane & 88 & 5 & Category II & 0.562 & 0.05 & 3.72 & 949 & 0.4 to 3 & $\begin{array}{l}\text { ATSDR (2005); USEPA } \\
\text { (2002b); Atkins et al. (1975); } \\
\text { USEPA (1971); USEPA } \\
\text { (2019) }\end{array}$ \\
\hline \multicolumn{10}{|c|}{ Organophosphates (1960s to present) } \\
\hline Chlorpyrifos & 223 & 1 & Category II & 0.059 & 0.24 & 4.70 & $\begin{array}{l}19 \text { to } \\
297\end{array}$ & 0.3 to 6 & $\begin{array}{l}\text { USEPA (2018b); WHO (2015); } \\
\text { USEPA (2011a); USEPA } \\
\text { (2019) }\end{array}$ \\
\hline Malathion & 5400 & 131 & Category IV & 0.156 & 0.38 & 2.80 & 0.3 to 7 & 0.156 to 7.5 & $\begin{array}{l}\text { USEPA (2018c); USEPA } \\
\text { (2016a) }\end{array}$ \\
\hline Diazinon & 1250 & 0.67 & Category III & 0.052 & 0.20 & 3.77 & 9 to 57 & 0.25 to 5 & $\begin{array}{l}\text { USEPA (2018d); USEPA } \\
\text { (2008); USDA (2018a) }\end{array}$ \\
\hline Methyl parathion & 4.5 & 0.44 & Category I & 0.111 & $0.04^{\alpha}$ & 2.86 & 11.25 & 0.5 to 2 & $\begin{array}{l}\text { USEPA (2009a); ATSDR } \\
\text { (2001); USEPA (1998); } \\
\text { USEPA (1999); Jones and } \\
\text { Connell (1954) }\end{array}$ \\
\hline Dichlorvos & 56 & 2.3 & Category I & 0.495 & 0.29 & 1.58 & 0.4 & 0.2 & $\begin{array}{l}\text { USEPA (2006a); USEPA } \\
\text { (2019) }\end{array}$ \\
\hline Phosmet & 113 & 1.5 & Category II & 0.22 & 0.37 & 2.95 & 2.67 & 0.7 to 6 & $\begin{array}{l}\text { EFSA (2006); USEPA (2006b); } \\
\text { ECHA (2015); USEPA } \\
\text { (2009b) }\end{array}$ \\
\hline Azinphos-methyl & 4.4 & 0.25 & Category I & 0.423 & 0.15 & 2.75 & 27 & 0.125 to 2.5 & $\begin{array}{l}\text { USEPA (2006c); ATSDR } \\
\text { (2008); Atkins et al. (1975); } \\
\text { USEPA (2019) }\end{array}$ \\
\hline
\end{tabular}


Table 1 (continued)

\begin{tabular}{|c|c|c|c|c|c|c|c|c|c|}
\hline Class/compound & $\begin{array}{l}\text { Rat } \\
\text { acute } \\
\text { oral } \\
\mathrm{LD}_{50} \\
(\mathrm{mg} / \mathrm{kg} \\
\text { bw) }\end{array}$ & $\begin{array}{l}\text { Rat } \\
\text { chronic } \\
\text { NOAEL } \\
\text { (mg/kg } \\
\text { bw/day) }\end{array}$ & $\begin{array}{l}\text { Mammalian } \\
\text { acute oral } \\
\text { toxicity } \\
\text { rating }{ }^{\gamma}\end{array}$ & $\begin{array}{l}\text { Honey } \\
\text { bee acute } \\
\text { contact } \\
\mathrm{LD}_{50}(\mu \mathrm{g} \\
\text { a.i./bee) }\end{array}$ & $\begin{array}{l}\text { Honey } \\
\text { bee acute } \\
\text { oral } L_{50} \\
\text { ( } \mu \text { g a.i./ } \\
\text { bee) }\end{array}$ & $\begin{array}{l}\log \\
K_{\text {ow }}\end{array}$ & $\begin{array}{l}\text { Aerobic } \\
\text { soil half- } \\
\text { life } \\
\text { (day) }\end{array}$ & $\begin{array}{l}\text { Max single } \\
\text { application } \\
\text { rate for } \\
\text { agriculture } \\
\text { (lb a.i./A) }\end{array}$ & Source(s) \\
\hline Fenitrothion & 330 & 2.74 & Category II & 0.02 & NA & 3.319 & 2 & 0.3125 to 3 & $\begin{array}{l}\text { USEPA (1995); FAO (2003); } \\
\text { USEPA (2010a) }\end{array}$ \\
\hline \multicolumn{10}{|c|}{ Pyrethroids (1970s to present) } \\
\hline Bifenthrin & 53.4 & 5 & Category II & 0.015 & 0.20 & 6.40 & $\begin{array}{l}65 \text { to } \\
250\end{array}$ & 0.036 to 0.5 & $\begin{array}{l}\text { USEPA (2010b); USEPA } \\
\text { (2017a); WHO (2017); } \\
\text { USEPA (2019) }\end{array}$ \\
\hline Permethrin & 340.5 & 125 & Category II & 0.024 & 0.131 & 6.10 & $\begin{array}{c}8.70 \text { to } \\
305\end{array}$ & 0.007 to 0.4 & $\begin{array}{l}\text { USEPA (2011b); USEPA } \\
\text { (2016b); FAO (2019b); } \\
\text { USEPA (2017b) }\end{array}$ \\
\hline Lambda-Cyhalothrin & 56 & 10 & Category II & 0.038 & 0.483 & 7.00 & $\begin{array}{r}28.2 \text { to } \\
60.5\end{array}$ & $\begin{array}{l}0.03 \text { to } \\
0.156\end{array}$ & $\begin{array}{l}\text { USEPA (2010c); USDA } \\
\quad(2018 \mathrm{~b})\end{array}$ \\
\hline Cypermethrin & 86 & 5 & Category II & 0.023 & 0.172 & 6.40 & $\begin{array}{c}12.7 \text { to } \\
170\end{array}$ & 0.025 to 0.1 & $\begin{array}{l}\text { USEPA (2012a); USEPA } \\
\quad(2016 \mathrm{c})\end{array}$ \\
\hline Deltamethrin & 66.7 & 5.8 & Category II & 0.0015 & 0.19 & 5.4 & $\begin{array}{l}22 \text { to } \\
54.6\end{array}$ & 0.13 to 0.21 & $\begin{array}{l}\text { USEPA (2017c); USEPA } \\
\text { (2016b) }\end{array}$ \\
\hline Fenpropathrin & 48.5 & 3 & Category I & 0.0015 & NA & 5.1 & $\begin{array}{r}155 \text { to } \\
709\end{array}$ & 0.04 to 0.3 & USEPA(2016b); (2016d) \\
\hline Cyfluthrin & 590 & 5.4 & Category III & 0.037 & $0.050^{\beta}$ & 6 & $\begin{array}{c}14.4 \text { to } \\
123\end{array}$ & $\begin{array}{r}0.048 \text { to } \\
0.192\end{array}$ & $\begin{array}{l}\text { USEPA (2017d); USEPA } \\
\text { (2016b); USEPA (2019) }\end{array}$ \\
\hline Esfenvalerate & 87.2 & 25.1 & Category II & 0.017 & NA & 75 & $\begin{array}{l}5.62 \text { to } \\
>6.2- \\
2\end{array}$ & $\begin{array}{r}0.096 \text { to } \\
0.184\end{array}$ & $\begin{array}{l}\text { USEPA (2017e); USEPA } \\
\text { (2016b) }\end{array}$ \\
\hline \multicolumn{10}{|c|}{ Neonicotinoids (1990s to present) } \\
\hline Thiamethoxam & 1563 & 61 & Category III & 0.024 & 0.005 & -0.13 & $\begin{array}{c}34.3 \text { to } \\
464\end{array}$ & 0.17 to 0.27 & $\begin{array}{l}\text { USEPA (2017f); USEPA } \\
\quad(2017 \mathrm{~g})\end{array}$ \\
\hline Imidacloprid & 424 & 16.5 & Category II & 0.043 & 0.0039 & 0.57 & $\begin{array}{r}172 \text { to } \\
608\end{array}$ & $\begin{array}{c}0.043 \text { to } \\
0.25\end{array}$ & $\begin{array}{l}\text { USEPA (2016e); USEPA } \\
\quad(2017 \mathrm{~h})\end{array}$ \\
\hline Clothianidin & $>5000$ & 31.2 & Category IV & 0.0275 & 0.0037 & 1.12 & $\begin{array}{l}144 \text { to } \\
5357\end{array}$ & 0.05 to 0.2 & $\begin{array}{l}\text { USEPA (2017g); USEPA } \\
\quad(2017 \mathrm{i})\end{array}$ \\
\hline Dinotefuran & 2000 & 241 & Category III & 0.047 & 0.0076 & -0.549 & 9 to 162 & $\begin{array}{c}0.068 \text { to } \\
0.54\end{array}$ & $\begin{array}{l}\text { USEPA (2017j); USEPA } \\
\quad(2017 \mathrm{k})\end{array}$ \\
\hline Acetamiprid & 146 & 17.9 & Category II & 10.53 & 8.96 & 0.8 & $\begin{array}{r}1.85 \text { to } \\
14.9\end{array}$ & 0.03 to 0.52 & $\begin{array}{l}\text { USEPA (20171); USEPA } \\
\quad(2017 \mathrm{~m})\end{array}$ \\
\hline Sulfoxaflor & 1000 & 6.07 & Category III & 0.379 & 0.146 & $<1$ & $\begin{array}{r}0.799 \text { to } \\
0.806\end{array}$ & $\begin{array}{r}0.012 \text { to } \\
0.133\end{array}$ & $\begin{array}{l}\text { USEPA (2012b); USEPA } \\
\text { (2019) }\end{array}$ \\
\hline Thiacloprid & 396 & 4.2 & Category II & 37.8 & 17.32 & 1.26 & $\begin{array}{r}1.2 \text { to } \\
7.1\end{array}$ & $\begin{array}{c}0.088 \text { to } \\
0.25\end{array}$ & $\begin{array}{l}\text { USEPA (2012c); USEPA } \\
\quad(2012 \mathrm{~d})\end{array}$ \\
\hline
\end{tabular}

Notes: NA, no risk assessment value available in the literature

${ }^{\alpha}$ Honey bee acute oral $\mathrm{LD}_{50}$ value for parathion as no value is available for methyl parathion

${ }^{\beta}$ Honey bee acute oral $\mathrm{LD}_{50}$ value for beta-cyfluthrin as no value is available for cyfluthrin

${ }^{\gamma}$ Category I, high toxicity; category II, moderate toxicity; category III, low toxicity; category IV, very low toxicity (as per Toynton et al. 2009 and USEPA 2018a)

intensive agriculture). Thus, it is unclear whether the observed species trends were in fact chemically induced or simply the result of associated land use change. Tew et al. $(1992,1994)$ reported that wood mice demonstrate a preference for field margins unsprayed by herbicides, presumably due to increased food availability (seeds and invertebrates). However, as indicated by Prosser et al. (2016), there is a considerable paucity of data necessary to quantitatively characterize 
indirect effects of herbicides in field margins. Schauber et al. (1997) established populations of herbivorous gray-tailed voles (Microtus canicaudus) and omnivorous deer mice (Peromyscus maniculatus) in enclosures ( 0.2 ha; $\sim 0.5$ acres) planted with alfalfa (Medicago sativa) and monitored mammal populations following direct application of the organophosphate insecticide azinphos-methyl at 0, 0.88 (0.8 lb/A), and $3.61 \mathrm{~kg} / \mathrm{ha}(3.2 \mathrm{lb} / \mathrm{A})$. Treatment with azinphos-methyl at $3.61 \mathrm{~kg} / \mathrm{ha}(3.2 \mathrm{lb} / \mathrm{A})$ reduced population density, growth, survival, recruitment, and body growth of voles, though exposure to $0.88 \mathrm{~kg} / \mathrm{ha}(0.8 \mathrm{lb} / \mathrm{A})$ resulted in no consistent effects. Moreover, azinphos-methyl did not detectably affect reproductive activity of female voles (Schauber et al. 1997). Deer mice densities were reduced by $47 \%$ after application of $3.61 \mathrm{~kg} / \mathrm{ha}(3.2 \mathrm{lb} / \mathrm{A})$, but no other adverse effects were significant, though variability was high. Consequently, the authors concluded that azinphos-methyl treatment primarily resulted in a short-term increase of mortality in small mammals, without long-term toxic effects (Schauber et al. 1997). Consequently, the available field data indicate that direct application of certain pesticides (i.e., organophosphates) can induce population changes in mammals when applied at high rates, though corresponding effects are ambiguous at lower rates, and direct effects of herbicides are inconclusive.

Relative toxicity of insecticide classes Based on a comparison of insecticide toxicity profiles (Table 1, Fig. 1a, b), using the rat as a representative model species for wildlife, mammalian toxicity of the neonicotinoids is markedly improved relative to previous classes of chemistry. Based on comparison of regulatory reported endpoints included for a broad subset of active ingredients representing each chemical class, on an acute basis, mammalian LD50s for neonicotinoids are $\sim 15 \times$ higher than the organochlorines (OCs), $\sim 10 \times$ higher than the pyrethroids, and nearly double $(1.8 \times)$ that of the organophosphates (OPs). Based on comparison of chronic toxicity, on average, mammalian reproductive NOAELs for neonicotinoids are $4.5 \times, 6.4 \times$, and $2.3 \times$ higher than the organochlorines, pyrethroids, and organophosphates, respectively. Generally, the organochlorines, pyrethroids, and many organophosphates would be deemed to have mammalian acute oral toxicities with a rating of category I or II (high or moderate toxicity, as per Toynton et al. 2009 and USEPA 2018a), while the neonicotinoids would be rated category II to IV (moderate to very low toxicity) (see Table 1).

Application rates of newer insecticide classes (i.e., pyrethroids and neonicotinoids) are lower than those that were required for organophosphates and organochlorines, and subsequently, typical exposure concentrations in the field would also be comparatively lower (Table 1). Without data regarding incidents attributed to older chemistries, it is not possible to determine the change in number of annual incidents with adoption of newer chemistries, but based on the toxicity data, a general decrease would be expected. However, as indicated by Stein et al. (2018), while improvements have been made in "chemical pollution" generated by agriculture, agrochemicals can still pose a potential risk to wildlife, especially if applied incorrectly, so continual assessment of risks, benefits, and best practices is necessary.

Incident reporting data Recent trends in reported mammalian mortality incidents in the USA were explored by mining data from the ProPharma Group database (ProPharma 2019). From January 2003 to July 2019, 474 mortalities were reported in mammals, of which 255 mortalities were dogs (54\%), 56 were cats $(12 \%)$, and 62 were cows (13\%) (Fig. 2). As such, domesticated animals represented the vast majority of the reported mammalian incidents potentially attributed to exposure to pesticides. With the exception of 2007, annual incidents have remained relatively stable or have declined slightly over the recorded period (Fig. 2). Rodenticides were deemed to be responsible for $24 \%$ of reported incidents in non-target species (note that rodents are among the species reported in the database but only in cases where the compound was not a rodenticide). Insecticides were cited in $36 \%$ of incidents, herbicides in $25 \%$ of incidents, fungicides in $9 \%$ of incidents, and the other $5 \%$ were either unknown compounds or combination products (e.g., insecticide/fungicide). Most often the route of exposure was unknown (i.e., not witnessed), so care must be taken in interpreting the incident data because exposure to the compound of interest cannot always be confirmed.

When pesticide incident data were examined by state, there was an apparent trend towards a greater number of reported mammalian mortality incidents in states with greater pesticide usage (based on usage data from Gianessi and Reigner 2006). However, the aforementioned incident data do not take into consideration land area (i.e., size/area of a given state) nor proportion of land attributed to agriculture. For example, Texas and California are the largest and second largest states in the contiguous USA and are ranked 1 st and 4 th in mammalian incidents, but rank 9 th and 22nd in terms of proportion of state land area identified as farmland (percent of total state area). In contrast, Nebraska and Kansas rank 35th and 30th in terms of reported mammalian incidents, but 1 st and 4 th in terms of percentage of land area identified as farmland (USDA ERS 2018). Therefore, adjusting for state land area and proportion land area attributed to agriculture indicates no evident trend between reported mammalian incidents and pesticide use (Fig. 3). However, when states are ranked according to population, there is an evident trend of a greater number of reported incidents corresponding to greater population size (Fig. 3). Intuitively, the greater the population size, the greater the likelihood of human-induced incidents.

Indirect effects on mammals With respect to potential indirect effects on prey items (i.e., invertebrates), available toxicity 

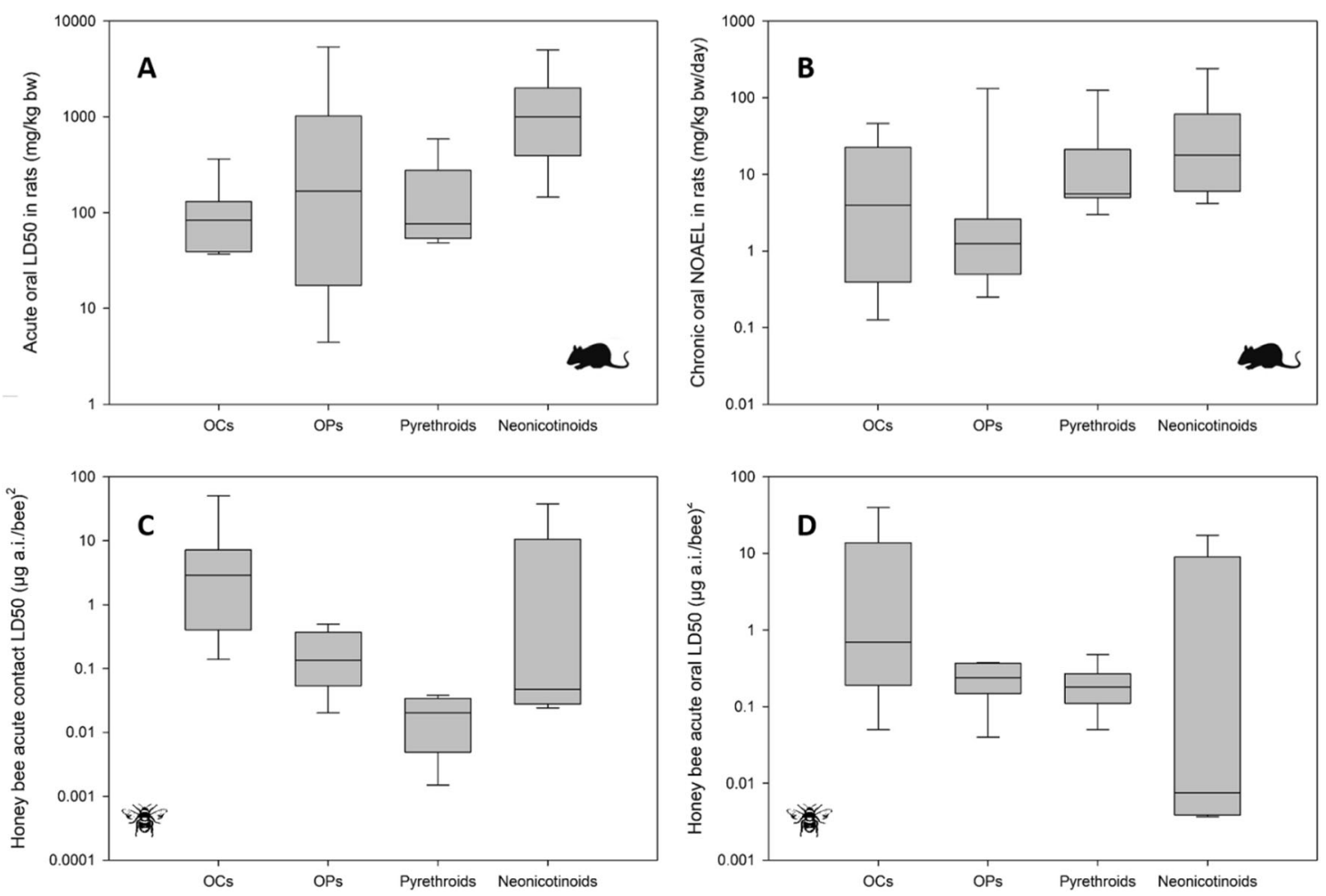

Fig. 1 Acute (a) and chronic (b) oral toxicity in rats, and acute contact (c) and oral (d) toxicity in honey bees of organochlorines (OCs), organophosphates (OPs), pyrethroids, and neonicotinoid active

ingredients listed in Table 1. Where values presented in Table 1 were non-definitive (e.g., $>5000 \mathrm{mg} / \mathrm{kg}$ ), the absolute value was graphed (i.e., $5000 \mathrm{mg} / \mathrm{kg})(n=1$ in (a), $n=3$ in (b))

data (i.e., honey bee acute contact and oral LD50s) for the OCs, OPs, pyrethroids, and neonicotinoids were compiled (Table 1; Fig. 1c, d) and compared. DiBartolomeis et al. (2019) proposed a method for calculating acute insecticide toxicity loading (AITL) in the USA accounting for total mass of insecticides used, acute toxicity to honey bees, and persistence in the environment. Based on "screening analysis," the authors concluded that the neonicotinoids were considerably more toxic to insects (i.e., honey bees) and generally persisted longer in the environment, despite being applied at

considerably lower application rates relative to previously developed insecticide classes (DiBartolomeis et al. 2019). However, targeted analysis of a broad subset of OCs, OPs, and pyrethroids relative to the neonicotinoids (Table 1; Fig. 1) does not support this conclusion. Generally, based on contact exposure, neonicotinoids are less potent to terrestrial invertebrates than the pyrethroids and directly comparable to the OCs and OPs with respect to honey bee toxicity (Table 1). Regarding oral toxicity, again based on the subset of insecticides considered (including all neonicotinoids with registered
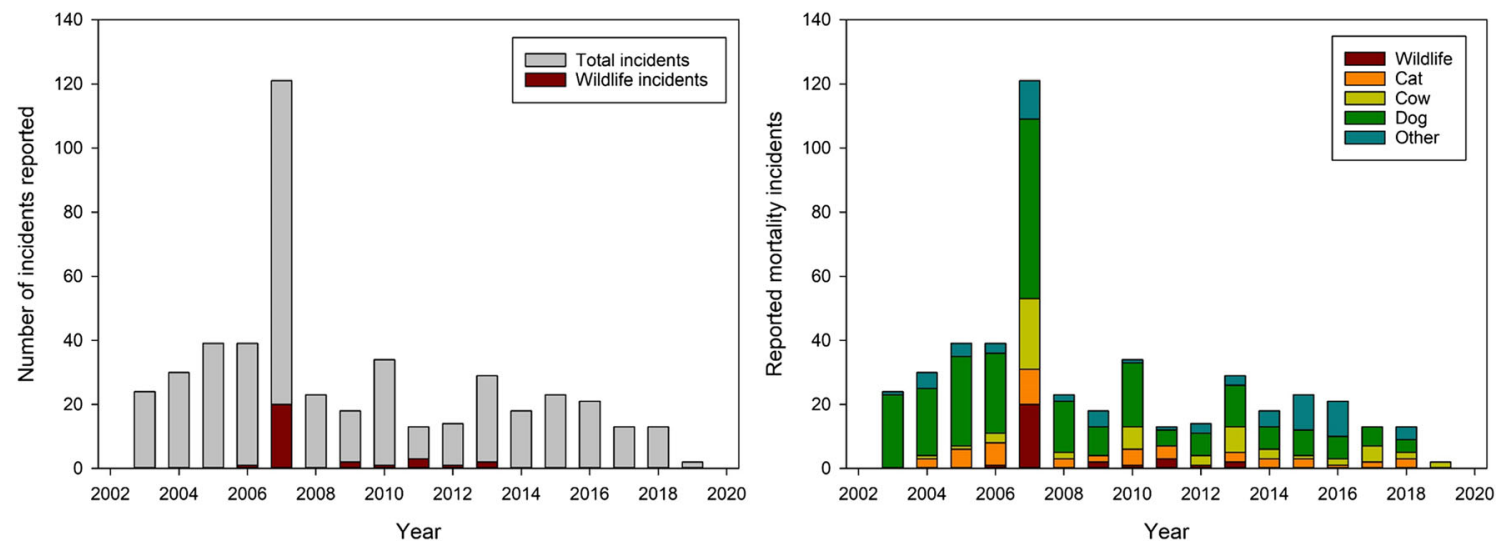

Fig. 2 Annual mammalian pesticide mortality incidents reported in the USA between 2003 and mid-2019, including those specifically designated as involving "wildlife," and the breakdown by species. Note

on February 20, 2007, there were 91 calls from a variety of locations, for a variety of animals, referring to a variety of different compounds 
Fig. 3 Total mammalian pesticide mortality incidents reported in the USA between 2003 and mid-2019 by state compared to a state total land area and agricultural area and $\mathbf{b}$ state total human population (as of 2018). While the size of the state and amount of land dedicated to agricultural activities did not seem to predict the number of mammalian mortality incidents, populated states experienced a greater number of incidents there was a trend whereby more
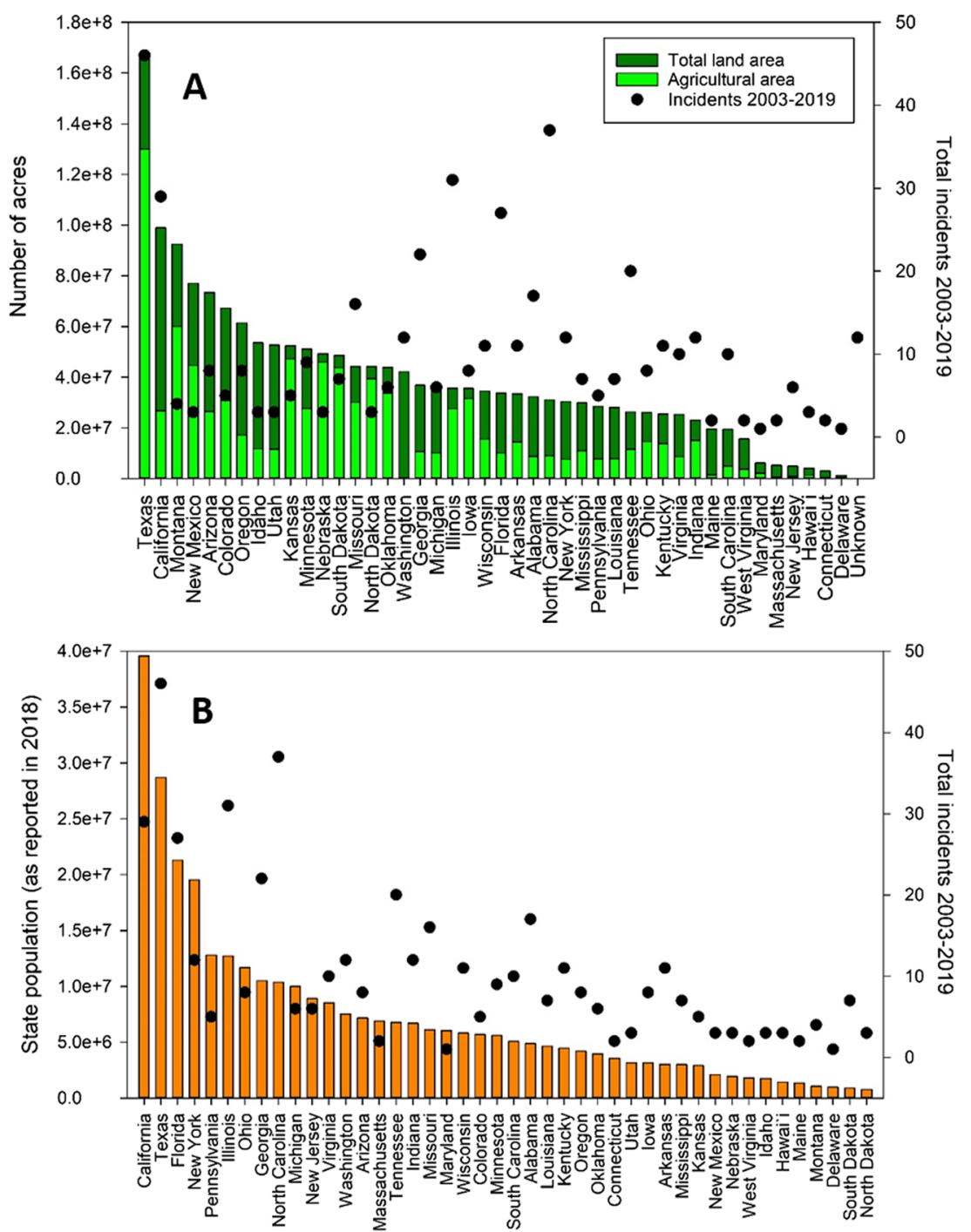

agricultural uses), on average, the classes are comparable, though the within-class variability can be quite large (Table 1; Fig. 1). Removing obvious outliers, including acetamiprid and thiacloprid (neonicotinoids) and toxaphene (organochlorine), the spectrum of sensitivity is still within an order of magnitude across all four classes. However, this does not account for the relative proportion of compounds applied within a given class. Moreover, soil persistence of neonicotinoids is, on average, comparable to the pyrethroids, greater than the OPs, but orders of magnitude shorter that the OCs. Application rates for neonicotinoids are also comparable to the pyrethroids, but $\sim 10 \times$ lower than that of the OPs and 10-100× lower than the OCs. Therefore, the conclusion that neonicotinoids have solely contributed to an increase in pesticide toxicity loading over the past 26 years is not supported by the available empirical data. Moreover, with respect to mammals, acute and chronic toxicity has improved markedly over successive generations of insecticide classes (Table 1; Fig. 1).

\section{Light pollution}

Although chemical pollution is often featured in the ecological apocalypse narrative, light pollution is now considered a key "bringer of insect apocalypse," according to the Guardian newspaper (The Guardian 2019). Notwithstanding the dramatic terminology, light pollution, or artificial light at night (ALAN), primarily from street, domestic, and vehicle lighting, can have catastrophic implications for invertebrates (Longcore and Rich 2004; Garrett et al. 2020) and vertebrates, particularly mammals (Russart and Nelson 2018). Russart and Nelson (2018) concluded from available laboratory and field data that exposure to light at night disrupts circadian and seasonal behavior in wildlife. Studies conducted in the laboratory tended to indicate that exposure to ALAN can shift the timing of foraging/food intake in nocturnal rodents to the daytime and alter typical timing of daily locomotor activity (Russart and Nelson 2018). Decreased anxiety-like behaviors were also observed in nocturnal rodents in response to even dim light at 
night, including spending greater time out in the open and an increased time rearing up, which are likely to be maladaptive responses in the wild (Russart and Nelson 2018). Given that $70 \%$ of mammals are nocturnal (Bennie et al. 2014), the potential implications of ALAN are consequential since photoperiodic animals rely on seasonal changes in day length in order to induce physiological and behavioral modifications in anticipation of favorable and unfavorable conditions for survival and reproduction (Russart and Nelson 2018). As indicated by Russart and Nelson (2018), ALAN can desynchronize seasonal reproductive activities by masking detection of short days and inappropriately signaling long days. Bennie et al. (2015) posited that the biomes experiencing the greatest increase in exposure to ALAN are often of high conservation importance, reflecting high levels of diversity, endemism, and rarity. As "sky glow" (ALAN) increases, further circadian and behavioral dysfunction can be anticipated, particularly in areas proximal to frontiers of urban expansion (Bennie et al. 2015).

\section{Urban/rural land use changes}

Trends and implications As discussed in Brain and Anderson (2019), current shifts from agricultural or forest land uses towards urban, suburban, and rural sprawl represent relatively minor proportions of the total available land mass in the contiguous USA, but urban land uses can have outsized impacts on wild species. This is true for birds, and perhaps is even more so for wild mammal species, particularly those with very large home ranges, sensitivity to human activity, and migratory lifestyles (Laliberte and Ripple 2004). Typically, urbanization of an area results in reduced total biodiversity and a distinct shift towards species suited to urban or disturbed environments (Bradley and Altizer 2006; Laliberte and Ripple 2004; Forman and Alexander 1998). The exact mechanism by which these changes occur can vary, but cities represent both a simplified habitat structure and an intersection of multiple stressors (e.g., air/noise/light pollution, novel disease transmission, changes to resource availability) (Bradley and Altizer 2006).

Wildlife case studies There were 16.1 million new homes constructed in the USA within 30 miles of wilderness areas between 1940 and 2000. Much of the relative and absolute growth was located in and around Florida, the Southwest, Southern California, Southern Appalachia, Colorado, Utah, and Washington - many of the same areas contain relatively high numbers of imperiled species (Flather et al. 2013). A study of 32 carnivores and 11 ungulates across North America found the greatest range and population contractions in larger-bodied species, and those residing in temperate grassland, savannah, and shrubland biomes (i.e., those biomes that have experienced considerable land use changes)
(Laliberte and Ripple 2004). Similarly, Flather et al. (2013) suggested that reductions in small game harvests could be in part a result of declines in species associated with farmland, grassland, and early successional habitats. As an example, in California, degree of urbanization was negatively correlated with occurrence of bobcats, striped skunks, gray foxes, and mountain lions. There was also a significant negative correlation between native species richness and urban land use (Ordeñana et al. 2010). However, populations of species that are more adaptable to co-habitation with humans (e.g., raccoons, coyotes) were positively correlated with urbanization (Ordeñana et al. 2010), and these species have experienced considerable range expansions with increased development, but this is atypical across taxa (Laliberte and Ripple 2004; Ordeñana et al. 2010; Stein et al. 2018).

Domestic cats One wildlife stressor typically associated with urban areas and often overlooked is domesticated and (semi-)feral cats. Descendent from the Old World wildcats, evidence suggests that co-occurrence of humans and "domestic" cats (descendent from Felis silvestris) first appeared in the Fertile Crescent approximately 9,000 years ago when cats were likely adopted by farmers for their observed ability to regulate rodent populations in grain stores (Driscoll et al. 2007; Ottoni et al. 2017; O'Brien and Johnson 2007). Subsequently, domestic cats arrived in North America from Europe after being introduced there by expansion of the Roman Empire from the Mediterranean. Currently, in the USA, cats are the most popular house pet, with a population of around 90 million, present in $34 \%$ of US homes ( $\mathrm{Zax}$ 2007). However, as presented in Brain and Anderson (2019), cats are the number one cause of bird mortality ( $70 \%$ ) in the USA. Likewise, they can significantly impact small mammal species, up to and including local extirpation (Baker et al. 2003; Frank et al. 2014; Denny and Dickman 2010). Spay/neuter efforts can manage future populations, but do not prevent short-term effects on individuals and local populations of prey species (Greenwell et al. 2019).

\section{Legal hunting and poaching}

Legal hunting Game species (i.e., those hunted for sport and/ or sustenance) comprise only a very small proportion of the total wildlife species in the USA, but hunting represents an important population driver for these species (Flather et al. 2013). A review of available mortality data for $69 \mathrm{mammal}$ populations (27 medium- to large-bodied species) in North America was conducted by Collins and Kays (2011) in an effort to characterize the major causes of wildlife mortality. Of the 2209 mortality events in the dataset, 1874 had known causes; of these, $51.7 \%$ were assigned to anthropogenic causes. Hunting represented $35.3 \%$ of known causes, predation accounted for $35.2 \%$, and vehicle collisions represented 
$9.2 \%$ (Fig. 4). The authors also found that smaller body mass was correlated to a higher predation risk (Collins and Kays 2011).

Illegal poaching Although largely considered an issue isolated to Asia and the African Savanna, poaching, or the illegal taking of wildlife, does occur in the USA (Muth and Bowe Jr. 1998). The Lacey Act (16 U.S.C. SS 3371-3378) was passed by Congress in 1900 making it unlawful to import, export, sell, acquire, or purchase fish, wildlife, or plants that are taken, possessed, transported, or sold. The law covers all fish and wildlife and their parts or products, plants protected by the Convention on International Trade in Endangered Species of Wild Fauna and Flora (CITES), and those protected by State law. Wildlife enforcement officials estimate that nearly 3,000 American black bears are illegally taken nationwide each year to supply gall bladders for Chinese medicine (Musgrave et al. 1993). Of the documented human-related causes of mortality in red wolf (Canis rufus) populations, poaching (suspected or confirmed gunshot/poison) accounted for 27 to $60 \%$ between 2013 and 2015 (US FWS 2016). However, of the estimated $35.3 \%$ of wildlife mortalities attributed to hunting by Collins and Kays (2011), poaching represented the cause in only $5.4 \%$ of known cases, with legal harvest comprising the larger share (29.9\% of total known cases). This suggests that for many commonly hunted species, legal hunting is a greater driver of mortality than illegal poaching. The authors also found that legal protection from harvesting reduced the susceptibility of monitored species to human-caused mortality by $44 \%$ (Collins and Kays 2011). However, legal hunting has also been a reliable source of funding to conservation programs

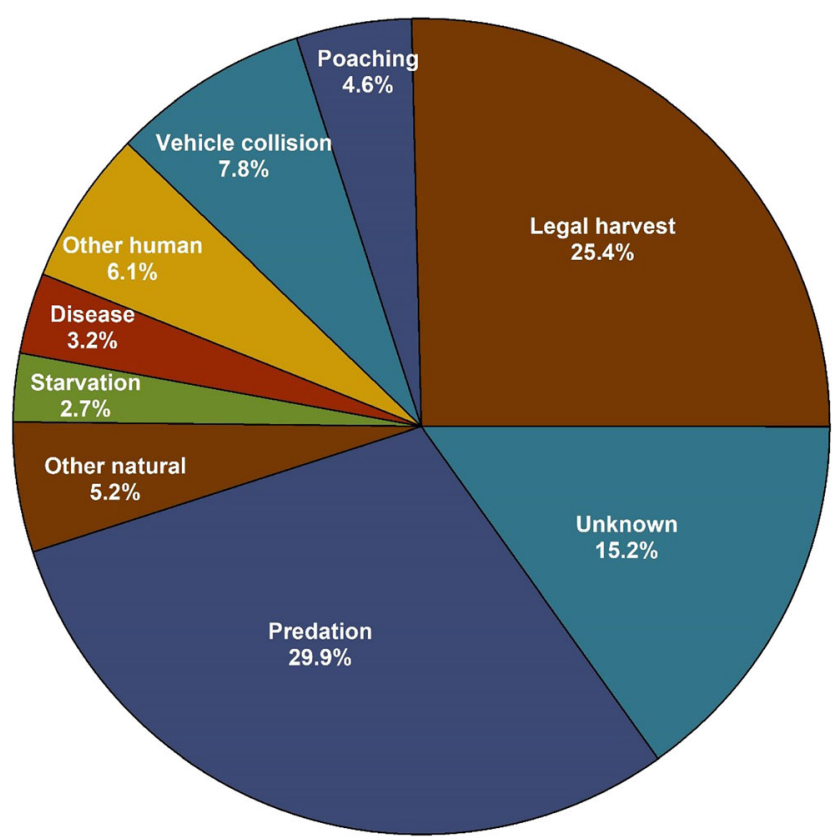

Fig. 4 Causes of mortality reported by Collins and Kays (2011) for medium and large North American mammal populations for management and restoration of wildlife species, providing over a billion dollars to state agencies (Association of Fish and Wildlife Agencies 2016).

Wildlife harvest trends While population and harvest data are limited to a small group of species (including mule deer, pronghorn, elk, white tail deer, squirrel, hare, and cottontail), trends suggest populations of the most commonly hunted species have stabilized or plateaued between 1975 and 2010 (Flather et al. 2013). Black bears have been the exception, with steady national and regional growth over the past 40 years. Furbearing harvests have averaged approximately 4.4 million pelts per year since 2000 (includes 28 furbearer species, but predominately muskrat and raccoon) (Flather et al. 2013). However, the number of active trappers is declining due to aging and a shift towards urban demographics (Flather et al. 2013). Likewise, previous studies have found a negative correlation between urbanization and hunting, so with a shift towards a more urban lifestyle, hunting pressures are expected to continue to decline (Collins and Kays 2011).

\section{Wildlife-vehicle collisions}

\section{Road land use and effect zones}

Public roads represent a relatively small land use category $(<$ $1 \%$ of the total land in the USA) but an important driver for wildlife mortality, particularly for susceptible species. According to the Bureau of Transportation Statistics, there are a total of 4,115,462 miles of public roads in the USA (BTS 2019a), where the total vehicle miles traveled is estimated at 3.2 trillion ( $\sim 2.25$ trillion urban and 963 billion rural) (BTS 2019b). Forman (2000) estimated that road effect zones cover more than $20 \%$ of the USA, and effects of roads range from habitat loss to direct vehicle mortality to nest/den abandonment due to noise/traffic to isolation of populations and potential for extirpation or extinction (Litvaitis and Tash 2008; Forman and Alexander 1998; Stein et al. 2018).

\section{Collision trends and statistics}

National crash databases estimate the total number of reported wildlife-vehicle collisions (WVCs) at 300,000 per year (Huijser et al. 2008). However, based on carcass count data, insurance industry information, police-reported crashes, and interviews with the public, the Federal Highway Administration (Huijser et al. 2008) estimates that there are between 1 and 2 million collisions between vehicles and animals in the USA every year, which is equivalent to one vertebrate mortality every 16 to $32 \mathrm{~s}$. Moreover, as indicated by Schwartz et al. (2018), surveys of roadkill estimates may severely underestimate the number of incidents given that $76 \%$ can be removed by scavengers within $12 \mathrm{~h}$. These estimates 
focus on medium to large-bodied mammals, while estimates of vertebrates in general are considerably higher, perhaps 365 million annually (Huijser et al. 2008).

Some species are at particular risk of additive rather than compensatory mortality (i.e., road-related deaths adding to total mortality rather than replacing another cause of mortality). This can be due to physiology (e.g., small clutch or litter sizes, long life expectancy) or other factors (e.g., few causes of adult mortality) (Litvaitis and Tash 2008; Huijser et al. 2008). Larger species tend to be more susceptible on secondary twolane highways, and smaller mammals are more likely to be struck by vehicles while crossing large, multi-lane highways (Forman and Alexander 1998). In over 95\% of reported cases, there is no human injury, but in most cases, the animal succumbs to its injuries immediately or after a short period. For example, white tail deer collisions in Michigan had a fatality rate of $91.5 \%$, while moose collisions in Newfoundland were $88.5 \%$ fatal (Huijser et al. 2008).

\section{Threatened and endangered species}

Huijser et al. (2008) also identified 21 federally listed species for which vehicle collisions posed a major survival threat. The eight mammalian species were Lower Keys marsh rabbit (Sylvilagus palustris hefneri), Key deer (Odocoileus virginianus clavium), bighorn sheep (Ovis canadensis), San Joaquin kit fox (Vulpes macrotis mutica), Canada lynx (Lynx canadensis), ocelot (Leopardus pardalis), Florida panther (Felis concolor coryi), and red wolf (Canis rufus). Many of these species are also significantly impacted by elements of urbanization beyond roads, so even eliminating vehicle mortalities will not completely alleviate the pressures facing these populations (Huijser et al. 2008). Even in national parks, considered sanctuaries for wildlife, vehicle strikes are alarmingly high. For example, the National Park Service reported 162 vehicle-related wildlife deaths in Grand Teton (WY) in a single year, including 48 elk, 41 deer, 17 bison, 6 pronghorn, 5 moose, 5 bears, and 2 wolves (NPS 2011). Not surprisingly, with over 272 million registered vehicles in the USA (BTS $2019 \mathrm{c}$ ), the probability of vertebrate strikes is calamitous.

\section{Invasive species}

The effect of invasive species on native flora and fauna can best be described as analogous to a plague of snakes, hogs, and "cheaters." Collectively, and individually, these species have had devastating ecological and economic impacts in the USA. Invasive species can cause negative effects on native wildlife populations through direct competition, disease transmission, habitat degradation, and/or displacement (Bergman et al. 2000; Pimentel et al. 2000). In addition, invasions can act synergistically with changes in land use, whereby an invasive species has a greater likelihood of becoming established in disturbed areas (Vitousek et al. 1997). For example, roadside weedy plants are able to establish after the initial disturbance caused by road construction and land use change, making the plants a result, not a cause, of changes to biodiversity in this case (Vitousek et al. 1997). In addition to changes in biodiversity and ecosystem structure, invasive species can negatively affect the economy, human health, and, importantly, native species (Vitousek et al. 1997; Bergman et al. 2000; Pimentel et al. 2000).

Many domestic species are technically considered invasive, including the "beloved" domestic cat. As indicated by the American Bird Conservancy (ABC 2019), the number of domestic cats has tripled in the past 40 years, with over 100 million feral and outdoor cats currently responsible for killing well over 1 billion birds. In addition, "livestock" can also be characterized as invasive, where, due to consumer demand/ lifestyle, there are nearly 94 million cattle, 72 million pigs/hogs, 5 million sheep/lambs, $\sim 3$ million goats, and nearly 4 million "equids" currently in the USA (NASS 2016). Some of the potential implications of non-native animal introduction on native species are described subsequently. [Full disclosure, I (Richard Brain) have four horses and one unredeeming cat (three horses and the unredeeming cat belong to my daughter), I also consume meat; my co-author (Julie) consumes a little meat and much dairy.]

\section{"The Dirty Dozen"}

The Washington Post (2015) published a list of the dozen "most destructive invasive animals in the U.S.," all which are listed below, and some of which are discussed (in addition to non-animal invasive species) in greater detail below due to their relevance to mammalian SSOs:

\section{Burmese python}

2. Emerald ash borer

3. Nutria (aka swamp rat)

4. European starling

5. Northern snakehead

6. Brown marmorated stink bug

7. Feral hog

8. Lionfish

9. Norway rat (aka brown or sewer rats)

10. Tegu

11. Asian citrus psyllid

12. Brown tree snake

Burmese python Burmese pythons, introduced from Asia, and now found throughout much of southern Florida, including all of Everglades National Park, have increased dramatically in both abundance and geographic range since 2000 (Dorcas et al. 2012). These constricting snakes consume a wide variety 
of mammals and birds, and subsequent to their introduction, raccoon observations have decreased $99.3 \%$, opossums $87.5 \%$, as well as reduced bobcat observations, with no observations of rabbits (Dorcas et al. 2012), indicating significant top-down pressure on prey populations.

Feral swine Feral swine represent a particularly successful invasive mammal in the USA, largely due to their adaptability and rapid reproduction (Bevins et al. 2014; Washington Post 2015; Giuliano and Tanner 2007). Native to Eurasia and North Africa, feral pigs were originally introduced into some US parks for hunting (Giuliano and Tanner 2007). Over the past 30 years, their range has expanded from 17 to 38 states, but they are considered most problematic in Florida, California, and Texas (Mapston 2007; Bevins et al. 2014). As described by Bevins et al. (2014), the combination of the feral swine's generalist diet and high population densities creates challenges for threatened and endangered species conservation efforts. These invasive organisms have been associated with declines in plant and animal species, including species listed as rare, threatened, endangered, and of special concern (USDA 2002 in Bevins et al. 2014). Moreover, losses from crop damage and livestock predation due to these voracious swine are estimated at $\$ 1$ billion in the USA alone (Bevins et al. 2014). In addition to causing damage to crops and livestock, feral pigs can serve as a reservoir for zoonotic diseases (Lewis and Conover 2017).

Insects Invasive insects in North America cost the economy an estimated $\$ 15$ to 30 billion USD annually ( $\$ 40$ billion USD if pathogens are included), primarily as a result of damage to agricultural crops, but also in forestry losses (Bradshaw et al. 2016; Paini et al. 2016). For example, emerald ash borer (Agrilus planipennis) causes significant damage and changes to forested swaths of land (Bradshaw et al. 2016; Herms and McCullough 2014), including urban forests (Kovacs et al. 2010). Dramatic losses of long-lived tree species have resulted in significant habitat degradation across North America, which is potentially devastating for wildlife species relying on ash and wooded habitats (Herms and McCullough 2014). In particular, given the popularity of ash trees in urban landscapes, loss of this species could leave few or no other tree options for wildlife species in these landscapes, and the resultant loss of ecological services offered by forests (Herms and McCullough 2014).

"Cheaters" Pimentel et al. (2000) argued that introduced species of plants, animals, and microbes have caused the extinction of more native species than nearly any other threat by effectively consuming, displacing, and destroying native species. For example, cheatgrass (Bromus tectorum) is generally considered a scourge of the Western USA (Leopold 1949), and its establishment has been implicated in the decreased abundance and diversity of small mammals in the Great Basin Desert, Utah (Freeman et al. 2014). First introduced to North America from Europe about the middle of the nineteenth century, this invasive annual is a prolific seed producer (150,000 seeds/lb) (Klemmedson and Smith 1964) that can take root while native perennial grasses are still dormant, effectively "cheating" during the winter. According to the US Fish and Wildlife Service (2017), cheatgrass is expanding at a rate of hundreds of acres per day, and it is estimated that this invasive plant will have expanded its land area by 5 times in the Great Basin within 30 years. This shift in ecosystem composition is particularly problematic for the greater sagegrouse, which relies on sage brush cover that is being supplanted by cheatgrass. Mule deer, sage sparrows, pygmy rabbits, cutthroat trout, spotted frogs, many reptiles, and a host of other native plant and animal species are also considered at risk as a result of cheatgrass (US FWS 2017). It was hypothesized that invasive cheatgrass has resulted in changes in the availability of preferred food and microhabitat by outcompeting native plants (which have more nutritional seeds than those of cheatgrass) and altering the local fire cycle (by staying green for a shorter period than native vegetation) (Freeman et al. 2014).

\section{Interplay between economic developmental status and invasive species}

With regard to invasive species, regions differ in both the level of threat from invaders and the level of response from government agencies (Early et al. 2016; Paini et al. 2016; WWF 2018). In general, higher income countries will have the strongest management systems for preventing and responding to invasions. The greatest risks for introduction of invasive species into these areas are via trade and imported products. In contrast, in developing regions, passenger travel and transport of live specimens in response to economic incentives are considered among the greatest risks (Early et al. 2016). Developing economies also often have more vulnerable food production systems, with greater proportional losses at stake should an invasive agricultural pest establish a foot hold (Early et al. 2016; Paini et al. 2016). Regardless of economic status or stage of development, biodiversity hotspots will experience worse outcomes as a result of an invader than regions with relatively low biodiversity to begin with (Early et al. 2016).

Around a third (40 of 124) of countries surveyed by Paini et al. (2016) had a high likelihood of invasion by any one invasive insect or pathogen. The USA and China were both significant sources of invasive species, but could also experience the greatest absolute costs of damage to agriculture from invasive species as a result of the sheer size of their respective agriculture industries (Paini et al. 2016; Turbelin et al. 2017). Mammals in Neotropical regions (e.g., South America) tend to 
suffer greater impacts due to invasive species and exploitation than those in near-Arctic regions (e.g., the USA and Canada) where habitat loss plays a more significant role (WWF 2018).

\section{Disease}

While disease is typically a natural part of the life-cycle and a way by which healthy populations are maintained and kept in check, there are less common cases where disease reaches epidemic proportions in wildlife populations. This is often a result of the pervasive movement of people and goods via migration and trade throughout the world which has facilitated the spread of infectious disease to humanity and wildlife to devastating effect, up to and including extinction events. For example, thought to have originated from the Korean peninsula early in the twentieth century (O'Hanlon et al. 2018), amphibian chytridiomycosis panzootic, caused by Batrachochytrium dendrobatidis, is responsible for a decline of at least 501 species and 90 presumed extinctions in the last 50 years (Scheele et al. 2019). This disease is considered to represent the greatest recorded loss of biodiversity attributable to a disease (Scheele et al. 2019).

\section{White-nose syndrome}

In the case of bats, prior to 2000, intentional killing by humans was the primary cause of mortality for these species. However, with the rise in wind turbine use and the outbreak of white-nose syndrome, these causes of mortality have become much more important drivers of declines in bat populations (O'Shea et al. 2016). White-nose syndrome (WNS) in bats, caused by the fungus Geomyces destructans, is another introduced strain of disease causing drastic effects in North America (Lorch et al. 2011). Since its discovery in the USA in 2006 (following suspected introduction from Europe), WNS has caused devastating losses in 7 bat species, particularly the little brown Myotis lucifugus species (Frick et al. 2010; O'Shea et al. 2016; Flather et al. 2013). In the northeastern USA, population declines were in excess of $75 \%$ within 2 years (Blehert et al. 2009). It is unknown at this point what the effect on ecosystem structure or function will be with a projected $99 \%$ regional extinction of $M$. lucifugus, and the geographic and biological extent of the damage in other species across North America (Frick et al. 2010; Flather et al. 2013).

\section{West Nile virus}

First introduced to North America in 1999, West Nile virus (WNV) has had significant impacts on native bird populations, with nearly $50 \%$ of species being affected (George et al. 2015). The rapid spread of WNV across North America between the years 1999 and 2003 has been associated with the death of millions of native wild birds that act as primary hosts to the virus (McLean 2006). According to the Centers of Disease Control and Prevention (CDC 2018), WNV has been detected in over 300 species of dead birds in the US; American crow populations have declined by up to $45 \%$ since the arrival of WNV (LaDeau et al. 2007).

\section{Domestic meets wild}

Agriculture-wildlife interfaces also represent opportunities for disease transmission from wildlife species to livestock and vice versa. Of the 86 livestock diseases reportable to the World Organization for Animal Health, 42 have a wildlife component to the transmission cycle of the responsible pathogen (Miller et al. 2013). Pneumonia, caused by Mycoplasma ovipneumoniae and transmitted by commingling domestic sheep and/or goats, is considered the dominant factor affecting bighorn sheep populations (Cassirer et al. 2018; Besser et al. 2013; Besser et al. 2012). As described by Besser et al. (2013), this species once numbered between 1.5 and 2 million in the nineteenth century, but had been reduced to just 15,000 to 18,000 by 1960 (Buechner 1960), being extirpated from much of its historical range in North America. Likewise, cattle were responsible for transmission of disease to native wood bison in Canada (Tessaro et al. 1990; Nishi et al. 2002) and bison and elk in Yellowstone National Park (Meagher and Meyer 1994; Meyer and Meagher 1995), species of conservation concern. Clearly, disease has the potential for significant effects on wildlife populations and also represents another way in which agriculture can impact wild populations.

\section{Differences in drivers and outcomes in developed versus developing regions-contrasting the USA with China and Brazil}

\section{Chronology of economic development}

The environmental Kuznets curve is an economic model that hypothesizes an inverted- $U$ relationship between income per capita and environmental degradation, representing a transition through stages of development of an economy (Stern 2017) (Fig. 5). According to this theory, early economic development is characterized by deforestation or other environmental degradation to expand agriculture. Subsequently, a threshold is achieved concurrent with a shift towards other industries, resulting in stabilization or reforestation as less land is needed for agriculture (LeBlois et al. 2017; Mills and Waite 2009; Sarkodie and Strezov 2018). A very similar theory is the forest transition (FT) hypothesis, which predicts three phases of development: 1. deforestation, 2. stagnation, and 3. reforestation (Wolfersberger et al. 2015). As with the 


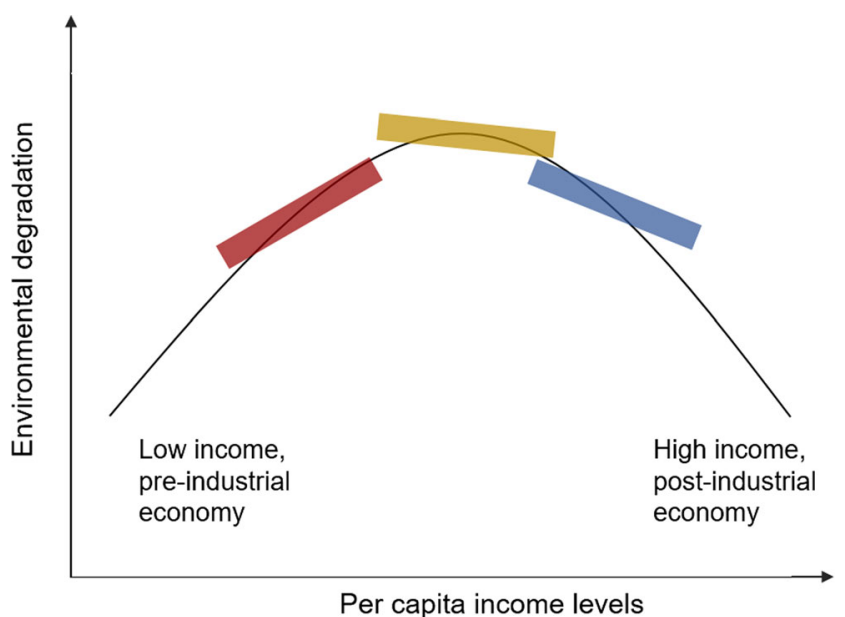

Fig. 5 Theoretical Kuznets curve - mapping slopes of cropland in production for the past 10-20 years in Brazil, China, and the USA (see Fig. 6) as surrogate for environmental degradation to demonstrate where along the development curve each of those countries lies

Kuznets curve, the FT hypothesis describes an income- and capital-driven shift from an agriculture-based economy to industry-based economy with concurrent agricultural intensification. In part, this shift occurs due to changing valuation of different land types, from a situation of relative abundance of forest lands (i.e., low value) and scarcity of agricultural land (i.e., high value) to the reverse situation where forests are relatively rare and highly valuable (Wolfersberger et al. 2015). While real-world testing of these hypotheses suggests there are other confounding variables that can drive environmental degradation (e.g., Mills and Waite 2009), analyses have found correlations between population and deforestation in developing countries (LeBlois et al. 2017 and references therein).

\section{Land use and economic development}

Economic developmental status defines the degree and nature of land conversion, varying along on a continuum between agrarian and industry/service-based economies. As a country develops and transitions from a predominantly agrarian-based society to a service/industry-based one, land conversion to agriculture decreases and ultimately gives way to urban expansion (Wolfersberger et al. 2015; Rudel et al. 2005). This paradigm is important because relative drivers/threats regarding species decline depend to some extent on the corresponding regional economic developmental status, as well as technology. Studies suggest that the "ecological, agronomic, and socio-economic characteristics of a region" will impact the effectiveness of strategies for mitigating the real and perceived conflict between biodiversity and agriculture (Smith et al. 2012). Stated another way, the drivers and relative strength of drivers for wildlife declines are expected to vary by region (Flather et al. 2013). In addition, as stated by LeBlois et al.
(2017), it is "reasonable to assume that forest policy and economic incentives related to land use also differ at distinct stages of development." This section explores some of those differences by contrasting the USA with China and Brazil, two countries at different stages of development (See UN 2019) with different population and resource pressures.

\section{Agriculture and forestry land use in the USA, China, and Brazil}

As reported in Brain and Anderson (2019), forest cover in the USA has been increasing over the past several decades and represents the largest land use category (USDA ERS 2018); however, the quality of secondary forest is not equal to that of primary forest (Noss et al. 1995). A challenge in tracking land use changes and the transition from deforestation to reforestation is that "forest" can be used in accounting for both primary and secondary forest, despite differences in quality and characteristics (Zhai et al. 2017). Thus, there may be the unintended consequence of masking continued loss of primary forest by replacement with forest plantations. This has become an issue in tropical regions of China where rubber plantations have driven deforestation but the metric of total planted area does not reflect this habitat degradation (Zhai et al. 2017). In Brazil, oil palm plantations have likewise been shown to support lower biodiversity than native forest, and in many cases, than other agricultural crops (Fitzherbert et al. 2008).

Prior to 1950, the forested area in China was generally decreasing as a result of conversion to agricultural land. However, cropland has been decreasing since the 1980s (Fig. 6), during which time there has been a shift from traditional to more modern farming technologies and, consequently, increased yields (Miao et al. 2016; He et al. 2012). Urbanization has occurred at a dramatic pace, increasing from $17.9 \%$ in 1978 to $40.5 \%$ in 2003 , and has resulted in conversion of over a million hectares of cropland to urban use (Miao et al. 2016). The political and cultural landscape of China is unique in that there has traditionally been a smallholder farm structure controlled by a central government (Miao et al. 2016). More recently, there has been a shift to more decentralized provincial and local governments, as well as a transition to a market economy (He et al. 2012). In China, because of the state land ownership and land use rights, local revenues from land leases and sales are used to fund infrastructure and development projects, making land finance a greater driver of urban expansion than population growth. This is different from the USA and other Western economies where land plays a more marginal role (He et al. 2012).

In 2006, the Brazilian government instituted a "Soy Moratorium" to slow the conversion of Amazonian rainforest to soybean plantation (Zalles et al. 2019). However, this agreement only applies to specific parts of the Amazon, and between 2006 and 2012, an additional 7 million ha of 
Fig. 6 Total cropland over time (1945 to 2010 or 2015) in the USA, China, and Brazil. Dashed lines indicate the percent of total land area comprised by cropland, showing a decrease over the last $30-40$ years in the USA, steady rate in China, and an increase in Brazil (based on data from USDA ERS 2018, Miao et al. 2016, He et al. 2012, and Dias et al. 2016)

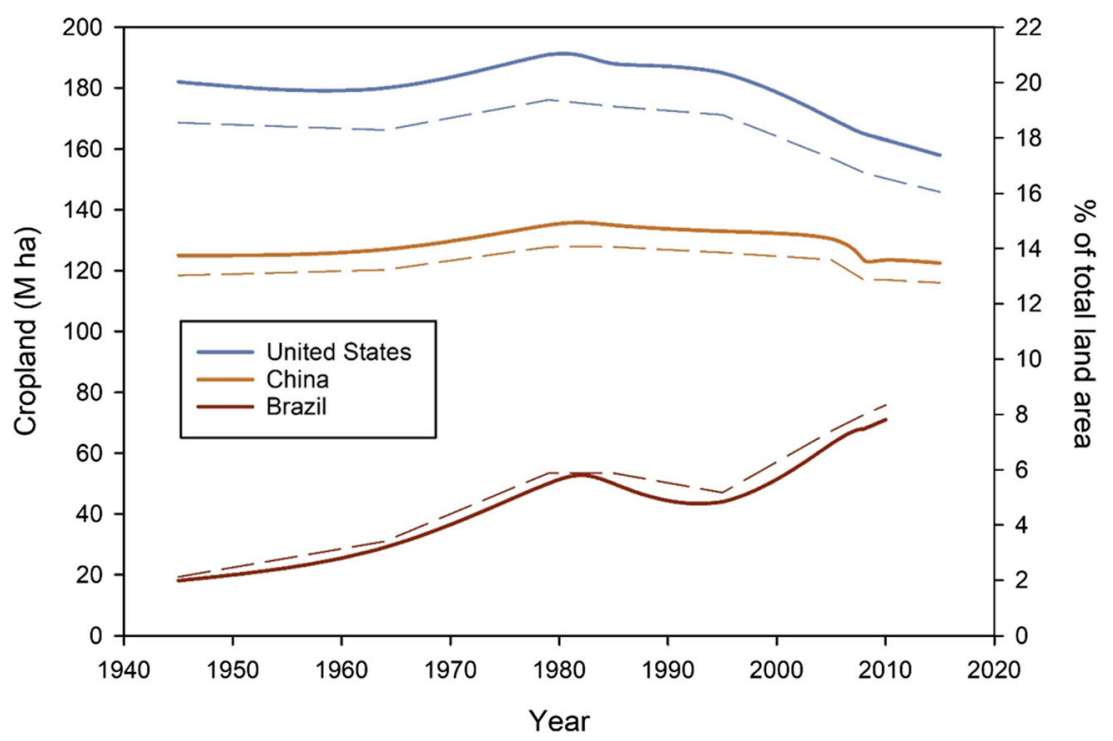

rainforest was converted to agricultural land, with total agricultural land generally increasing over the past several decades (Dias et al. 2016) (Fig. 6). As of 2016, the annual rate of deforestation in the Brazilian rainforest was 798,900 ha/ year (INPE 2016), primarily for conversion to agriculture. Moreover, the number of forest fires in Brazil in 2019 was the highest since 2010, suggesting that the current increased level of deforestation may be driven by more salient political and economic developmental considerations (Science Magazine 2019).

\section{Global trends and connectivity}

Globally, both the quantity and quality of forests are in decline (WWF 2018). Much of the current deforestation in developing regions is driven by trade and industrial-scale agriculture, as opposed to subsistence farming for local populations (LeBlois et al. 2017). In fact, increasing demand for soybeans has been a significant driver of land use change and agricultural intensification in Brazil (Richards 2015; Zalles et al. 2019). Soybean crops have been credited with poverty reductions and movement into the global middle class for 30 million people in Brazil between 2005 and 2015, a result of increasing soybean prices, local migration and displacement of smallholder farmers and ranchers, and new land clearing (Richards 2015). Soybean imports to China expanded from around $\$ 2$ billion in 2000 to $\$ 35$ billion in 2014, and an additional 20.1 million ha of cropland were put into production in Brazil over that period (Zalles et al. 2019). During the same period, biofuel policies in the USA and Europe were increasing corn production and driving up prices for soybean, another factor in increasing soybean production in Brazil (Richards 2015).

Given the degree to which economies and markets are globally connected, it becomes clear that many driving forces can work to change land use, agricultural practices, crop choice, and consequently, the balance between development/ resource exploitation and conservation priorities. Positive correlations have been determined between deforestation and GDP, population density, agricultural production, corruption, public policies, quality of governance, and openness to trade, making all of these drivers for deforestation in developing regions (LeBlois et al. 2017; Wolfersberger et al. 2015), which in turn can affect wildlife species. Brazil is an interesting case in this context, as it represents a likely candidate for agricultural intensification (favorable climate, large productive land area), is a major exporter, has exceptional biodiversity to begin with, and also faces some political variability (Dias et al. 2016; UN 2018; Zalles et al. 2019).

As indicated by Smith et al. (2012), coordination of land use policy and research agendas focusing on improving agronomic and ecological functioning is essential, necessitating knowledge integration of the ecological, agronomic, and economic developmental considerations specific to a particular region. Thus, conservation strategies need to be region-specific, cognizant of the resultant implications potentially associated with economic developmental status. Accordingly, where gains in biodiversity result in minimal costs to production, education and awareness may be effective; however, formal incentives will likely be necessary if the potential cost to production becomes significant (Smith et al. 2012).

\section{Discussion and conclusions}

People affect their environment, and they have done so since the dawn of humanity. Whether residing in an urban metropolis or the rural countryside, whether a consumer or producer, inevitably all $\sim 7$ billion humans affect our environment in a variety of ways. We all affect our environment and the 
environment affects all of us, so collectively we should all step back and take stock of what is most important and relevant with respect to improving species status outcomes. No matter what, we have to eat, and thus our fate is tied to the farmer, as it has been for at least 10,000 years. As the bumper stickers rightfully point out "no farms, no food," and consequently no future. Agriculture is the foundation of civilization, but also a primary means by which we control and change our environment. However, continual land use conversion to agriculture is not sustainable, though neither is consumption of agricultural land and natural habitat for the purposes of urban expansion. Land use change is dynamic and influenced by a complex milieu of social, political, and economic forces that vary by developmental status. The agricultural footprint has generally plateaued in developed countries, and is often experiencing contraction at the behest of urban expansion. In contrast, developing countries are expanding the agricultural footprint at the expense of native habitat, and often in areas considered to be oases for biodiversity. Consequently, stemming the tide of land conversion requires producing more agricultural output from less land, and with a projected population of $\sim 9$ billion by 2050 , biodiversity hangs in the balance.

Over the past 80 years in the USA, average corn, cotton, and soybean yields have risen $\sim 8$-fold, $\sim 4$-fold, and $\sim 3$-fold, respectively (Fernandez-Cornejo et al. 2014), with a concomitant plateauing (and even reduction) of agricultural land (USDA ERS 2018). This quantum leap in production has primarily been ascribed to pesticides and fertilizers (Fernandez-Cornejo et al. 2014). This analysis therefore exposes a philosophical dilemma regarding the perceived risks of pesticides versus the potential risks of land conversion. Although pesticides are often implicated in the popular media, risk is relative, necessitating context relative to other factors. Moreover, the benefits of pesticides in terms of counteracting other drivers of wildlife imperilment, particularly habitat loss, are seldom considered. Previous analyses focusing on the status of bird populations in the USA indicated that feral and domestic cats are responsible for $\sim 70 \%$ of bird mortalities annually and collisions with buildings/vehicles were responsible for a further 25\% of bird mortalities (Brain and Anderson 2019). By comparison, "poisons" as a general class, without breaking out pesticides, accounted for $\sim 2 \%$, highlighting the disparity in reality versus perception. Similarly, when considering other vertebrates, such as mammals, the potential risks associated with pesticide use should be considered relative to implications of land use change, invasive species, disease, vehicle collisions, light pollution, poaching, and other factors.

So, to revisit the question posed initially, relatively speaking, to what degree do pesticides contribute to wildlife SSOs in the USA compared to land use change, invasive species, disease, "road-kill," light pollution, poaching, and legal hunting? Based on the empirical evidence, the answer appears to be very little. Conservative estimates of vehicle strikes alone dwarf potential pesticide-related mortalities. While pesticides represent a rather ancillary risk relative to other factors, this is decidedly not the same as inconsequential risk, and thus vigilance should continue to be the l'ordre du jour (order of the day) as a general ethos. Pesticides require rigorous regulatory evaluation and oversight, though, the potential risks posed are de minimis by comparison.

Logically, this brings us to the second question, why the fixation on pesticides? Perhaps the answer is too philosophical, too politically, and socially sensitive to adequately address here. However, the narrative implying an outsized influence of pesticides on SSOs propagated in the popular media is inconsistent with reality and suggests a propensity towards sensationalism rather than facts. Pesticides are an easy target; they have a contentious and tainted legacy, demonstrate plausible physiological relevance, and are susceptible to litigious opportunism. Unequivocally, Rachel Carson (Carson 1962) got it right over half a century ago. However, the resultant implementation of regulatory oversight, manifested in the form of the US EPA, as well as passage of necessary legislation, seems generally overlooked in the contemporary narrative. Fidelity of physiological processes between target and non-target organisms creates a premise for biological relevancy (Fukuto 1990); however, evolutionary continuity alone does not predicate ecological risk. Moreover, in the USA, pesticides are subject to an easily exploited legal construct, facilitating litigation propagation. Being an easy target does not mean pesticides are the right target, and this fixation can potentially detract from public awareness regarding the primary drivers affecting SSOs, as well as the opportunity to proactively address them.

Developed nations have set a precedent for quality of life, driving global appetites and markets in developing regions. Consequently, it is unrealistic to expect the economic developmental benchmark regarding quality of life to change. However, the rate and nature of change of land conversion can be modified. The technology exists to feed the world, and pesticides, fertilizers, and genetically modified crops are all factors (albeit not the only ones) necessary to achieving this objective. Concomitantly, appropriate stewardship and mitigation are requisite co-factors to achieving this objective of sustainably because "the expected continuation of agricultural intensification this century should be able to support increasing demand for richer diets, but may not be compatible with long-term environmental sustainability" (Miao et al. 2016). These are macro-scale challenges; nonetheless, there are things we can all do at the micro scale to help improve wildlife SSOs. Managing the introduction and proliferation of invasive species, restricting opportunities for disease transmission between domestic livestock and wildlife, paying attention while driving, turning the lights off, using dimmers, low-glare fixtures and LED lights, etc., reducing our carbon footprint, or simply being engaged and informed can make a profound 
difference. Of course, continued vigilance in pesticide application is important, though yield intensification through technological innovation is a requisite reality irrecoverably tied to the reality of human expansion. Notwithstanding, investment in conservation activities is a logical solution where appropriate. As individuals, we account for one in 7 billion, but collectively, we account for a solution...

Funding information Funding for this work was provided by Syngenta Crop Protection LLC.

Financial interests Richard A. Brain is an employee of Syngenta Crop Protection, LLC and Julie C. Anderson is consultant to Syngenta Crop Protection LLC.

Open Access This article is licensed under a Creative Commons Attribution 4.0 International License, which permits use, sharing, adaptation, distribution and reproduction in any medium or format, as long as you give appropriate credit to the original author(s) and the source, provide a link to the Creative Commons licence, and indicate if changes were made. The images or other third party material in this article are included in the article's Creative Commons licence, unless indicated otherwise in a credit line to the material. If material is not included in the article's Creative Commons licence and your intended use is not permitted by statutory regulation or exceeds the permitted use, you will need to obtain permission directly from the copyright holder. To view a copy of this licence, visit http://creativecommons.org/licenses/by/4.0/.

\section{References}

American Bird Conservancy (ABC) (2019). Cats and other invasives. Available online: https://abcbirds.org/threat/cats-and-otherinvasives/. Accessed 24 Nov 242019

Andersen L.W. and J. Weihing (1959). EC59-1591 potato disease and insect control recommendations for 1959. Historical materials from University of Nebraska-Lincoln extension, volume 3483. Available online: http://digitalcommons.unl.edu/extensionhist/3483. [Accessed September 20, 2019]

Association of Fish and Wildlife Agencies (2016). The future of America's fish and wildlife: a $21^{\text {st }}$ century vision for investing in and connecting people to nature. Blue Ribbon Panel on Sustaining America's Diverse Fish and Wildlife Resources. 12 pp. Available online: https://www. fishwildlife.org/application/files/8215/1382/2408/Blue_Ribbon Panel_Report2.pdf. [Accessed November 26, 2019]

Atkins EL, Greywood EA, Macdonald RL (1975) Toxicity of pesticides and other agricultural chemicals to honey bees: laboratory studies. Division of Agricultural Sciences, University of California. Leaflet 2287. Printed December 1975. 40 pp

Baker PJ, Ansell RJ, Dodds PAA, Webber CE, Harris S (2003) Factors affecting the distribution of small mammals in an urban area. Mammal Rev 33(1):95-100

Bar-On YM, Phillips R, Milo R (2018) The biomass distribution on Earth. Proc Natl Acad Sci 115(25):6506-6511

British Crop Production Council (BCPC) (2018) A world compendium: the pesticide manual eighteenth edition. Turner, JA Editor. pp. 1400

Bennie JJ, Duffy JP, Inger R, Gaston KJ (2014) Biogeography of time partitioning in mammals. Proc Natl Acad Sci USA 111(38):1372713732

Bennie J, Duffy J, Davies T, Correa Cano M, Gaston K (2015). Global trends in exposure to light pollution in natural terrestrial ecosystems. Remote Sensing 7:2715-2730
Benton TG, Vickery JA, Wilson JD (2003) Farmland biodiversity: is habitat heterogeneity the key? Trends Ecol Evol 18(4):182-188

Bergman DL, Chandler MD, Locklear A (2000) The economic impact of invasive species to wildlife services' cooperators. Human Conflicts with Wildlife: Economic Considerations. 21

Besser TE, Cassirer EF, Yamada C, Potter KA, Herndon CN, Foreyt WJ, Knowles DP, Srikumaran S (2012) Survival of bighorn sheep (Ovis canadensis) commingled with domestic sheep (Ovis aries) in the absence of Mycoplasma ovipneumoniae. J Wildl Dis 48(1):168-172

Besser TE, Cassirer EF, Highland MA, Wolff P, Justice-Allen A, Mansfield K, Davis MA, Foreyt W (2013) Bighorn sheep pneumonia: sorting out the cause of a polymicrobial disease. Prev Vet Med 108(2-3):85-93

Bevins SN, Pedersen K, Lutman MW, Gidlewski T, Deliberto TJ (2014) Consequences associated with the recent range expansion of nonnative feral swine. BioScience. 64(4):291-299

Blehert DS, Hicks AC, Behr M, Meteyer CU, Berlowski-Zier BM, Buckles EL, Coleman JT, Darling SR, Gargas A, Niver R, Okoniewski JC (2009) Bat white-nose syndrome: an emerging fungal pathogen? Science. 323(5911):227-227

Bradley CA, Altizer S (2006) Urbanization and the ecology of wildlife diseases. Trends Ecol Evol 22(2):95-102. https://doi.org/10.1016/j. tree.2006.11.001

Bradshaw CJA, Leroy B, Bellard C, Roiz D, Albert C, Fournier A, Barbet-Massin M, Salles J-M, Simard F, Courchamp F (2016) Massive yet grossly underestimated global costs of invasive insects. Nat Commun 7. https://doi.org/10.1038/ncomms 12986

Brain RA, Anderson JC (2019) The agro-enabled urban revolution, pesticides, politics, and popular culture: a case study of land use, birds, and insecticides in the USA. Environ Sci Pollut Res 26(21):21717-21735

Brashares JS, Abrahms B, Fiorella KJ, Golden CD, Hojnowski CE, Marsh RA, McCauley DJ, Nuñez TA, Seto K, L. Withey L. (2014) Wildlife decline and social conflict. Science. 345(6195):376-378

Brooks GT (1974) Chlorinated insecticides: technology and application volume I. CRC Press, 18901 Cranwood Parkway, Cleveland, Ohio, U.S.A 44128. pp 260

Buechner HK (1960) The bighorn sheep in the United States, its past, present, and future. Wildl Monogr 4:3-174

Bureau of Transportation Statistics (BTS) (2019a) Public road length, miles by functional system. Available online: https://www.bts.gov/ content/public-road-length-miles-functional-system. [Accessed September 1, 2019]

Bureau of Transportation Statistics (BTS) (2019b) Roadway vehiclemiles traveled (VMT) and VMT per lane-mile by functional class. Available online: https://www.bts.gov/content/roadway-vehiclemiles-traveled-vmt-and-vmt-lane-mile-functional-class. [Accessed September 1, 2019]

Bureau of Transportation Statistics (BTS) (2019c) Number of U.S. aircraft, vehicles, vessels, and other conveyances. Available online: https://www.bts.gov/content/number-us-aircraft-vehicles-vesselsand-other-conveyances. [Accessed September 1, 2019]

Carson R (1962) Silent spring. Houghton Mifflin Company, Boston

Cassirer EF, Manlove KR, Almberg ES, Kamath PL, Cox M, Wolff P, Besser TE (2018) Pneumonia in bighorn sheep: risk and resilience. J Wildl Manag 82(1):32-45. https://doi.org/10.1002/jwmg.21309

Centers of Disease Control and Prevention (CDC) (2018) Species of dead birds in which West Nile virus has been detected, United States, 1999-2016. Available online: https://www.cdc.gov/westnile/ resources/pdfs/BirdSpecies1999-2016.pdf. [Accessed September 1, 2019]

Central Intelligence Agency (CIA) (2019) World fact book. Available online: https://www.cia.gov/library/publications/the-worldfactbook/fields/385.html [Accessed September 24, 2019]

Collins C, Kays R (2011) Causes of mortality in North America populations of large and medium-sized animals. Anim Conserv 14:474 483 
Davis SC, Boundy RG (2019) Transportation energy data book: edition 37. Oak Ridge National Laboratory, U.S. Department of Energy. $410 \mathrm{pp}$. Available online: https://tedb.ornl.gov/ [Accessed September 24, 2019]

Denny EA, Dickman C (2010) Review of cat ecology and management strategies in Australia. Invasive Animals Cooperative Research Centre, Canberra, ACT, p 85

DeWitt JB (1956) Chronic toxicity to quail and pheasants of some chlorinated insecticides. Agric Food Chem 4(10):863-866

Dias LC, Pimenta FM, Santos AB, Costa MH, Ladle RJ (2016) Patterns of land use, extensification, and intensification of Brazilian agriculture. Glob Chang Biol 22(8):2887-2903

DiBartolomeis M, Kegley S, Mineau P, Radford R, Klein K (2019) An assessment of acute insecticide toxicity loading (AITL) of chemical pesticides used on agricultural land in the United States. PLoS One 14(8)

Dorcas ME, Willson JD, Reed RN, Snow RW, Rochford MR, Miller MA, Meshaka WE, Andreadis PT, Mazzotti FJ, Romagosa CM, Hart KM (2012) Severe mammal declines coincide with proliferation of invasive Burmese pythons in Everglades National Park. Proc Natl Acad Sci 109(7):2418-2422

Driscoll CA, Menotti-Raymond M, Roca AL, Hupe K, Johnson WE, Geffen E, Harley EH, Delibes M, Pontier D, Kitchener AC, Yamaguchi N, O'Brien SJ, Macdonald DW (2007) The Near Eastern origin of cat domestication. Science. 317(5837):519-523

Early R, Bradley BA, Dukes JS, Lawler JJ, Olden JD, Blumenthal DM, Gonzalez P, Grosholz ED, Ibañez I, Miller LP, Sorte CJB, Tatem AJ (2016) Global threats from invasive alien species in the twenty-first century and national response capacities. Nat Commun 7. https:// doi.org/10.1038/ncomms 12485

Eaton-Gonzalez R, Mellink E (2015) One shared region and two different change patterns: land use change in the binational Californian Mediterranean region. Land. 4(4):1138-1154

European Chemicals Agency (ECHA) (2015) CLH report: proposal for harmonized classification and labelling, based on Regulation (EC) No 1272/2008, Annex VI, Part 2. Phosmet. EC Number 211-987-4; CAS Number 732-11-6, Index Number 015-101-00-5. Version 2, July 29 2015. Available online: https://echa.europa.eu/documents/ 10162/13626/clh report phosmet en.pdf. [Accessed November $18,2019]$

European Food Safety Authority (EFSA) (2006) Conclusion regarding the peer review of the pesticide risk assessment of the active substance phosmet. Scientific Report (2006) 75, 1-72. Available online: https://doi.org/10.2903/j.efsa.2006.75r. [Accessed November 18, 2019]

Fernandez-Cornejo J, Nehring R, Osteen C, Wechsler S, Martin A, Vialou A (2014) Pesticide use in U.S. agriculture: 21 selected crops, 1960-2008, EIB-124, U.S. Department of Agriculture, Economic Research Service, May 2014, pp 86

Fingerling G, Hertkorn N, Parlar H (1996) Formation and spectroscopic investigation of two hexachlorobornanes from six environmentally relevant toxaphene components by reductive dechlorination in soil under anaerobic conditions. Environ Sci Technol 30(10):2984-2992

Fitzherbert EB, Struebig MJ, Morel A, Danielsen F, Brühl CA, Donald PF, Phalan B (2008) How will oil palm expansion affect biodiversity? Trends Ecol Evol 23(10):538-545

Flather CH, Knowles MS, Jones MF, Schilli C (2013) Wildlife population and harvest trends in the United States: a technical document supporting the Forest Service 2010 RPA Assessment. Gen. Tech. Rep. RMRS-GTR-296. Fort Collins, CO: U.S. Department of Agriculture, Forest Service, Rocky Mountain Research Station, 94 $\mathrm{pp}$

Food and Agriculture Organization of the United Nations (FAO) (1967) 1967 Evaluations of some pesticide residues in food. FAO/PL:1967/ M/11/1. WHO/Food Add./68.30. Rome. Available online: http:// www.inchem.org/documents/jmpr/jmpmono/v067pr07.htm. [Accessed September 10, 2019]

Food and Agriculture Organization of the United Nations (FAO) (2003) Fenitrothion (037). 55 pp. Available online: http://www.fao.org/ fileadmin/templates/agphome/documents/Pests Pesticides/JMPR/ Evaluation03/fenitrothion_2003.pdf. [Accessed November 18, 2019]

Food and Agriculture Organization of the United Nations (FAO) (2009) How to feed the world in 2050. Office of the Director, agricultural development economics division economic and social development department, Viale delle Terme di Caracalla 00153 Rome, Italy. 35 pp. Available online: http://www.fao.org/fileadmin/templates/wsfs/ docs/expert_paper/How to Feed the World_in_2050.pdf. [Accessed September 24, 2019]

Food and Agriculture Organization of the United Nations (FAO) (2019a) FAOSTAT. Available online : http://www.fao.org/faostat/en/\# home. [Accessed September 10, 2019]

Food and Agriculture Organization of the United Nations (FAO) (2019b) FAO specifications and evaluations for agricultural pesticides: permethrin. 167 pp. Available online: http://www.fao.org/3/ca5414en/ ca5414en.pdf. [Accessed November 12, 2019]

Forman TT (2000) Estimate of the area affected ecologically by the road system in the United States. Conserv Biol 14(1):31-35

Forman TT, Alexander LE (1998) Roads and their major ecological effects. Annu Rev Ecol Syst 29(1):207-231

Francey N, Chapman S (2000) "Operation Berkshire": the international tobacco companies' conspiracy. Br Med J 321(7257):371-374. https://doi.org/10.1136/bmj.321.7257.371

Frank ASK, Johnson CN, Potts JM, Fisher A, Lawes MJ, Woinarski JCZ, Tuft K, Radford IJ, Gordon IJ, Collis M-A, Legge S (2014) Experimental evidence that feral cats cause local extirpation of small mammals in Australia's tropical savannas. J Appl Ecol 51(6):14861493

Freeman ED, Sharp TR, Larsen RT, Knight RN, Slater SJ, McMillan BR (2014) Negative effects of an exotic grass invasion on small mammal communities. PLoS One 9(9):e108843. https://doi.org/10.1371/ journal.pone. 0108843

Frick WF, Pollock JF, Hicks AC, Langwig KE, Reynolds DS, Turner GG, Butchkoski CM, Kunz TH (2010) An emerging disease causes regional population collapse of a common North American bat species. Science. 329(5992):679-682

Fukuto TR (1990) Mechanism of action of organophosphorus and carbamate insecticides. Environ Health Perspect 87:245-254

Garrett JK, Donald PF, Gaston KJ. 2020. Skyglow extends into the world's key biodiversity areas. Animal Conservation. 23: 153-159

Gaston KJ (2005) Biodiversity and extinction: species and people. Prog Phys Geogr 29(2):239-247

George TL, Harrigan RJ, LaManna JA, DeSante DF, Saracco JF, Smith TB (2015) Persistent impacts of West Nile virus. Proc Natl Acad Sci 112(46):14290-14294. https://doi.org/10.1073/pnas.1507747112

Gianessi L, Reigner N (2006) Pesticide use in U.S. crop production2002. Insecticides and other pesticides. CropLife Foundation. Available online: http://www.allergytx.com/resources/pdf/ PesticideUseinUSCropProduction2002Report.pdf. [Accessed October 21, 2019]

Gibbs KE, Mackey RL, Currie DJ (2009) Human land use, agriculture, pesticides and losses of imperiled species. Divers Distrib 15(2):242253

Giuliano WM, Tanner GW (2007) Ecology of wild hogs in Florida. IFAS Extension, University of Florida

Goulson D, 232 signatories (full list available online) (2018) Call to restrict neonicotinoids. Science 360(6392):973

Greenwell CN, Calver MC, Loneragan NR (2019) Cat gets its tern: a case study of predation on a threatened coastal seabird. Animals. 9(7): 445 
Hansen V (2012) The Silk Road: a new history. Oxford University Press. ISBN-10: 0190218428; ISBN-13: 978-0190218423, Oxford, p 328

He C, Huang Z, Wang W (2012) Land use changes and economic growth in China. Lincoln Institute of Land Policy Land Lines 2012:14-19

Health Canada Pest Management Regulatory Agency (PMRA) (2011) Confidor 200 SL containing imidacloprid. Evaluation Report ERC 2011-03 63

Health Canada Pest Management Regulatory Agency (PMRA) (2018) Thiamethoxam, Actara 25WG Insecticide, Actara 240SC Insecticide, and other related end-use products. Proposed Registration Decision PRD2018-14, 86 pp

Health Canada Pest Management Regulatory Agency (PMRA) (2019) Dinotefuran and related end-use products. Proposed Registration Decision PRD2019-01, 73 pp

Herms DA, McCullough DG (2014) Emerald ash borer invasion of North America: history, biology, ecology, impacts, and management. Annu Rev Entomol 59:13-30

Hudson RH, Tucker RK, Haegele MA (1984) Handbook of acute toxicity of pesticides to wildlife, resource publication 153. U.S. Department of Interior, Fish and Wildlife Service, Washington, DC, pp 6-54

Huijser MP, McGowen P, Fuller J, Hardy A, Kociolek A, Clevenger AP, Smith D, Ament R (2008) Wildlife-vehicle collision reduction study: report to congress. U.S. Department of Transportation, Federal Highway Administration Report FHWA-HRT-08-034, pp 254

Imhoff ML, Bounoua L, Ricketts T, Loucks C, Harriss R, Lawrence WT (2004) Global patterns in human consumption of net primary production. Nature. 429(6994):870-873

Isenring R (2010) Pesticides and the loss of biodiversity: how intensive pesticide use affects wildlife populations and species diversity. Pesticide Action Network (Europe), pp 28

Jones GG, Connell JU (1954) Studies of the toxicity to worker honeybees (Apis mellifera L.) of certain chemicals used in plant protection. Ann Appl Biol 41(2):271-279

Killeen TJ, Calderon V, Soria L, Quezada B, Steininger MK, Harper G, Solórzano LA, Tucker CJ (2007) Thirty years of land-cover change in Bolivia. Ambio. 36(7):600-606

Klemmedson JO, Smith JG (1964) Cheatgrass (Bromus tectorum L.). Bot Rev 30(2):226-262

Kovacs KF, Haight RG, McCullough DG, Mercader RJ, Siegert NW, Liebhold AM (2010) Cost of potential emerald ash borer damage in U.S. communities, 2009-2019. Ecol Econ 69(3):569-578

LaDeau SL, Kilpatrick AM, Marra PP (2007) West Nile virus emergence and large-scale declines of North American bird populations. Nature. 447(7145):710-713

Laliberte AS, Ripple WJ (2004) Range contractions of North American carnivores and ungulates. BioScience. 54(2):123-138

LeBlois A, Damette O, Wolfersberger J (2017) What has driven deforestation in developing countries since the 2000s? Evidence from new remote-sensing data. World Dev 92:82-102

Leopold A (1949) A Sand County almanac, and sketches here and there. Oxford Univ. Press, New York

Lewis RJ, Conover MR (2017) Feeding a hungry world: threats to agriculture by invasive vertebrate species in the United States. Ecology and Management of Terrestrial Vertebrate Invasive Species in the United States. CRC Press, pp 99-106

Litvaitis JA, Tash JP (2008) An approach towards understanding wildlife-vehicle collisions. Environ Manag 42(4):688-697

Longcore T, Rich C (2004) Ecological light pollution. Front Ecol Environ 2(4):191-198

Lorch JM, Meteyer CU, Behr MJ, Boyles JG, Cryan PM, Hicks AC, Ballmann AE, Coleman JT, Redell DN, Reeder DM, Blehert DS (2011) Experimental infection of bats with Geomyces destructans causes white-nose syndrome. Nature. 480(7377):376-378

Maes J, Barbosa A, Baranzelli C, Zulian G, e Silva FB, Vandecasteele I, Hiederer R, Liquete C, Paracchini ML, Mubareka S, Jacobs-Crisioni
C (2015) More green infrastructure is required to maintain ecosystem services under current trends in land-use change in Europe. Landsc Ecol 30(3):517-534

Mapston ME (2007) Feral hogs in Texas. Texas Cooperative Extension. Wildlife Services

Martin H (1968) Pesticide manual: basic information on the chemicals used as active components of pesticides. British Crop Protection Council, United Kingdom; 1st Edition. ASIN:B0007JCE76.pp. 464

McEwen LC, Brown RL (1966) Acute toxicity of dieldrin and malathion to wild sharp-tailed grouse. J Wildl Manag 30:604-611

McLean R (2006) West Nile virus in North American birds. Ornithol Monogr 60:44-64

Meagher M, Meyer M (1994) On the origin of brucellosis in bison of Yellowstone National Park: a review. Conserv Biol 8(3):645-653

Meyer ME, Meagher M (1995) Brucellosis in free-ranging bison (Bison bison) in Yellowstone, Grand Teton, and Wood Buffalo National Parks: a review. J Wildl Dis 31(4):579-598

Miao L, Zhu F, Sun Z, Moore JC, Cui X (2016) China's land-use changes during the past 300 years: a historical perspective. Int J Environ Res Public Health 13(9):847-862

Miller RS, Farnsworth ML, Malmberg JL (2013) Diseases at the livestock-wildlife interface: status, challenges, and opportunities in the United States. Prev Vet Med 110(2):119-132

Mills JH, Waite TA (2009) Economic prosperity, biodiversity conservation, and the environmental Kuznets curve. Ecol Econ 68(7):20872095

Musgrave RS, Parker S, Wolok M (1993) The status of poaching in the United States - are we protecting our wildlife. Nat Resour J 33:9771014

Muth RM, Bowe JF Jr (1998) Illegal harvest of renewable natural resources in North America: toward a typology of the motivations for poaching. Soc Nat Resour 11(1):9-24

Myers N, Mittermeier RA, Mittermeier CG, da Fonseca GAB, Kent J (2000) Biodiversity hotspots for conservation priorities. Nature. 403(6772):853-858

Nash RG, Woolson EA (1967) Persistence of chlorinated hydrocarbon insecticides in soils. Science. 157(3791):924-927

National Agricultural Statistics Service (NASS) (2016) Overview of U.S. livestock, poultry, and aquaculture production in 2016. Available online: https://www.aphis.usda.gov/animal health/nahms/ downloads/Demographics2016.pdf. [Accessed November 24, 2019]

National Institute for Space Research (INPE) (2016) Ministry of science, technology, innovations and communications. Brazil. Available online: http://www.inpe.br/noticias/noticia.php?Cod_Noticia $=4344$. [Accessed September 10, 2019]

National Parks Service (NPS) (2011) Park officials troubled by increase in wildlife-vehicle collisions. Available online: https://www.nps. gov/grte/learn/news/increased-wildlife-vehicle-collisions.htm. [Accessed September 1, 2019]

Nishi JS, Stephen C, Elkin BT (2002) Implications of agricultural and wildlife policy on management and eradication of bovine tuberculosis and brucellosis in free-ranging wood bison of northern Canada. Ann N Y Acad Sci 969(1):236-244

Noss RF, Scott JM, LaRoe ET (1995) Endangered ecosystems of the United States: a preliminary assessment of loss and degradation. U.S. Fish and Wildlife. Research and Development., U.S. Fish and Wildlife. U.S. Dept. of the Interior, National Biological Service, Washington, D.C., p 95

O'Brien SJ, Johnson WE (2007) The evolution of cats. Sci Am 297(1): 68-75

O'Hanlon SJ, Rieux A, Farrer RA, Rosa GM, Waldman B, Bataille A, Kosch TA, Murray KA, Brankovics B, Fumagalli M, Martin MD (2018) Recent Asian origin of chytrid fungi causing global amphibian declines. Science. 360(6389):621-627 
O'Shea TJ, Cryan PM, Hayman TS, Plowright RK, Streiker DG (2016) Multiple mortality events in bats: a global review. Mammal Rev 46(3):175-190

Ordeñana MA, Crooks KR, Boydston EE, Fisher RN, Lyren LM, Siudyla S, Haas CD, Harris S, Hathaway SA, Turschak GM, Miles AK, Van Vuren DH (2010) Effects of urbanization on carnivore species distribution and richness. J Mammal 91(6):1322-1331

Organization for Economic Cooperation and Development (OECD) (2018) Biodiversity conservation and sustainable use in Latin America: evidence from environmental performance reviews, Paris, $\mathrm{p} 77$

Ottoni C, Van Neer W, De Cupere B, Daligault J, Guimaraes S, Peters J, Spassov N, Prendergast ME, Boivin N, Morales-Muñiz A, Bălășescu BC, Benecke N, Boroneant A, Buitenhuis H, Chahoud J, Crowther A, Llorente L, Manaseryan N, Monchot H, Onar V, Osypińska M, Putelat O, Morales EMQ, Studer J, Wierer U, Decorte R, Grange T, Geigl E-M (2017) The palaeogenetics of cat dispersal in the ancient world. Nat Ecol Evol 1(7):0139. https://doi. org/10.1038/s41559-017-0139

Paini DR, Sheppard AW, Cook DC, De Barro PJ, Worner SP, Thomas MB (2016) Global threat to agriculture from invasive species. Proc Natl Acad Sci 113(27):7575-7579

Pimentel D, Lach L, Zuniga R, Morrison D (2000) Environmental and economic costs of nonindigenous species in the United States. BioScience. 50(1):53-65

ProPharma (2019) ProPharma Group. Case Explorer, Version 4.9.6. 09/ 28/2015. Copyright 1997-2011. Available online: https:// caseexplorer.prosarcorp.com/Account/SignOn?ReturnUrl=\%2f. [Accessed October 4, 2019]

Prosser RS, Anderson JC, Hanson ML, Solomon KR, Sibley PK (2016) Indirect effects of herbicides on biota in terrestrial edge-of-field habitats: a critical review of the literature. Agric Ecosyst Environ 232:59-72

Rees WE (1992) Ecological footprints and appropriated carrying capacity: what urban economics leaves out. Environ Urban 4(2):121-130

Richards P (2015) What drives indirect land use change? How Brazil's agriculture sector influences frontier deforestation. Ann Am Assoc Geogr 105(5):1026-1040

Roberts D, Tren R, Bate R, Zambone J (2016) The excellent powder: DDT's political and scientific history. Dog Ear Publishing, p 452

Rudel TK, Coomes OT, Moran E, Achard F, Angelsen A, Xu J, Lambin E (2005) Forest transitions: towards a global understanding of land use change. Glob Environ Chang 15(1):23-31

Russart KLG, Nelson RJ (2018) Artificial light at night alters behavior in laboratory and wild animals. J Exp Zool A Ecol Integr Physiol 329(8-9):401-408

Sarkodie SA, Strezov V (2018) Empirical study of the environmental Kuznets curve and environmental sustainability curve hypothesis for Australia, China, Ghana and USA. J Clean Prod 201:98-110

Satterthwaite D, McGranahan G, Tacoli C (2010) Urbanization and its implications for food and farming. Philos Trans R Soc B 365(1554): 2809-2820

Schauber EM, Edge WD, Wolff JO (1997) Insecticide effects on small mammals: influence of vegetation structure and diet. Ecological Applications 7 (1):143-157

Scheele BC, Pasmans F, Skerratt LF, Berger L, Martel A, Beukema W, Acevedo AA, Burrowes PA, Carvalho T, Catenazzi A, De la Riva I (2019) Amphibian fungal panzootic causes catastrophic and ongoing loss of biodiversity. Science 363(6434):1459-63

Schwartz AL, Williams HF, Chadwick E, Thomas RJ, Perkins SE (2018) Roadkill scavenging behaviour in an urban environment. J Urban Ecol 4(1):1-7

Science Magazine (H. Escobar) (2019) There's no doubt that Brazil's fires are linked to deforestation, scientists say. August 26, 2019. Available online: https:/www.sciencemag.org/news/2019/08/ theres-no-doubt-brazils-fires-are-caused-deforestation-scientists-say [Accessed September 24, 2019]

Seto KC, Reenberg A, Boone CG, Fragkias M, Haase D, Langanke T, Marcotullio P, Munroe DK, Olah B, Simon D (2012) Urban land teleconnections and sustainability. Proc Natl Acad Sci 109(20): $7687-7692$

Sidebotham (2011. ISBN 0520948386, 9780520948389) Steven E. Berenike and the Ancient Maritime Spice Route, 1st edn. University of California Press, p 456

Smith FP, Gorddard R, House APN, McIntyre S, Prober SM (2012) Biodiversity and agriculture: production frontiers as a framework for exploring trade-offs and evaluating policy. Environ Sci Policy 23:85-94

Statistics Canada (2019) Table 32-10-0153-01: total area of farms and use of farm land, historical data. https://doi.org/10.25318/3210015301eng [Accessed October 17, 2019]

Stein BA, Edelson N, Anderson L, Kanter J, Stemler J (2018) Reversing America's wildlife crisis: securing the future of our fish and wildlife. National Wildlife Federation, Washington, DC, $36 \mathrm{pp}$

Stern DI (2017) The environmental Kuznets curve. Oxford Research Encyclopedia of Environmental Science. Available online: https:// doi.org/10.1093/acrefore/9780199389414.001.0001/acrefore9780199389414-e-401 [Accessed August 28, 2019]

Tauger MB (2011) Agriculture in world history. Themes in world history, 1st edn. Routledge, New York, p 208

Tessaro SV, Forbes L, Turcotte C (1990) A survey of brucellosis and tuberculosis in bison in and around Wood Buffalo National Park, Canada. Can Vet J 31(3):174-180

Tew TE, Macdonald DW, Rands MRW (1992) Herbicide application affects microhabitat use by arable wood mice (Apodemus sylvaticus). J Appl Ecol 29:532-539

Tew TE, Todd IA, MacDonald DW (1994) Field margins and small mammals. In: Boatman N (ed) British crop protection council monograph; Field Margins: Integrating Agriculture and Conservation. British Crop Protection Council, pp 85-94

The Guardian (2019) Light pollution is key 'bringer of insect apocalypse'. D Carrington (Ed) November 22, 2019. Available online: https://www.theguardian.com/environment/2019/nov/22/lightpollution-insect-apocalypse. [Accessed November 25, 2019]

Thompson RL (2007) Challenges facing the food and agricultural sector, sustainability in the food \& agricultural sector: the role of the private sector and government. In: Proceedings of the $40^{\text {th }}$ International Food and Agricultural Trade Policy Council Seminar, Stratford-upon-Avon, United Kingdom

Toynton K, Luukinen B, Buhl K, Stone D (2009) Permethrin technical fact sheet; National Pesticide Information Center, Oregon State University Extension Services. Available online: http://npic.orst. edu/factsheets/archive/Permtech.html. [Accessed September 17, 2019]

Tscharntke T, Clough Y, Wanger TC, Jackson L, Motzke I, Perfecto I, Vandermeer J, Whitbread A (2012) Global food security, biodiversity conservation and the future of agricultural intensification. Biol Conserv 151(1):53-59

Tudge C (1998) Neanderthals, bandits and farmers: how agriculture really began. Yale University Press, New Haven and London ISBN 0-29784258-7 and ISBN 0-300-08024-7

Turbelin AJ, Malamud BD, Francis RA (2017) Mapping the global state of invasive alien species: patterns of invasion and policy responses. Glob Ecol Biogeogr 26(1):78-92

United States Environmental Protection Agency (USEPA) (2019) ECOTOX user guide: ECOTOXicology Knowledgebase System. Version 5.0. Available online: http://www.epa.gov/ecotox/. Accessed 22 Nov 2019

Underwood EC, Viers JH, Klausmeyer KR, Cox RL, Shaw MR (2009) Threats and biodiversity in the Mediterranean biome. Divers Distrib 15(2):188-197 
United Nations (UN) (2017) World population projected to reach 9.8 billion in 2050, and 11.2 billion in 2100 . United Nations Department of Economic and Social Affairs. Available online: https:/www.un.org/development/desa/en/news/population/worldpopulation-prospects-2017.html. [Accessed April 6, 2020]

United Nations (UN) (2018) World economic situation and prospects. 207 pp. Available online: https://www.un.org/development/desa/ dpad/wp-content/uploads/sites/45/publication/WESP2018_Full Web-1.pdf [Accessed August 30, 2019]

United Nations (UN) (2019) United Nations office of the high representative for the least developed countries, landlocked developing countries, and small island developing states. Available online: http://unohrlls.org/about-ldcs/criteria-for-ldcs/ [Accessed August 29, 2019]

United States Department of Agriculture (USDA) (2002) Management of predation losses to state and federally endangered, threatened, and species of special concern; and feral hog management to protect other state and federally endangered, threatened, and species of special concern, and candidate species of fauna and flora in the state of Florida. US Department of Agriculture Animal and Plant Health Inspection Service, Wildlife Services. pp 64

United States Department of Agriculture (USDA) (2018a) Draft human health and ecological risk assessment for diazinon in exotic fruit fly applications. April 2018, pp 49

United States Department of Agriculture (USDA) (2018b) Draft human health and ecological risk assessment for lambda-cyhalothrin in exotic fruit fly applications. April 2018, 37 pp

United States Department of Agriculture Economic Research Service (USDA ERS) (2018) Major land uses, data products. Available online: https://www.ers.usda.gov/data-products/major-land-uses/ [Accessed August 28, 2019]

United States Department of Human Health Services, Public Health Service, Agency for Toxic Substances and Disease Registry (ATSDR) (1989). Toxicological profile for heptachlor/heptachlor epoxide. April 1989. Available online: https://nepis.epa.gov/Exe/ ZyPDF.cgi/9101SKS3.PDF?Dockey=9101SKS3.PDF. [Accessed September 4, 2019]

United States Department of Human Health Services, Public Health Service, Agency for Toxic Substances and Disease Registry (ATSDR) (2001) Toxicological profile for methyl parathion. September 2001. Available online: https://www.atsdr.cdc.gov/ ToxProfiles/tp48.pdf. [Accessed September 4, 2019]

United States Department of Human Health Services, Public Health Service, Agency for Toxic Substances and Disease Registry (ATSDR) (2002a) Toxicological profile for DDT, DDE, and DDD. September 2002. Available online: https://www.atsdr.cdc. gov/toxprofiles/tp35.pdf. [Accessed September 6, 2019]

United States Department of Human Health Services, Public Health Service, Agency for Toxic Substances and Disease Registry (ATSDR) (2002b) Toxicological profile for aldrin/dieldrin. September 2002. Available online: https://www.atsdr.cdc.gov/ toxprofiles/tp1.pdf. [Accessed September 6, 2019]

United States Department of Human Health Services, Public Health Service, Agency for Toxic Substances and Disease Registry (ATSDR) (2005) Toxicological profile for alpha-, beta-, gamma-, and delta-hexachlorocyclohexane. $377 \mathrm{pp}$. Available online: https:// www.atsdr.cdc.gov/toxprofiles/tp43.pdf. [Accessed November 18, 2019]

United States Department of Human Health Services, Public Health Service, Agency for Toxic Substances and Disease Registry (ATSDR) (2008) Toxicological profile for guthion. Available online: https://www.atsdr.cdc.gov/ToxProfiles/tp188.pdf. [Accessed November 18, 2019]

United States Department of Human Health Services, Public Health Service, Agency for Toxic Substances and Disease Registry (ATSDR) (2014) Toxicological profile for toxaphene. $291 \mathrm{pp}$.
Available online: https://www.atsdr.cdc.gov/toxprofiles/tp94.pdf. [Accessed November 18, 2019]

United States Department of Human Health Services, Public Health Service, Agency for Toxic Substances and Disease Registry (ATSDR) (2018) Toxicological profile for chlordane. $252 \mathrm{pp}$. Available online: https://www.atsdr.cdc.gov/toxprofiles/tp31.pdf. [Accessed November 18, 2019]

United States Department of Human Health Services, Public Health Service, Agency for Toxic Substances and Disease Registry (ATSDR) (2019) Toxicological profile for mirex and chlordecone. Draft for public comment, May 2019. 332 pp. Available online: https://www.atsdr.cdc.gov/ToxProfiles/tp66.pdf. [Accessed November 18, 2019]

United States Environmental Protection Agency (USEPA). (1960) (archive). Pesticide product label, HEPTACHLOR $20 \%$ GRANULAR, 02/17/1960. Available online: https://www3.epa. gov/pesticides/chem_search/ppls/000148-00406-19600217.pdf. [Accessed September 6, 2019]

United States Environmental Protection Agency (USEPA) (1969) T \& C $74 \%$ chlordane (label). Available online: https://www3.epa.gov/ pesticides/chem_search/ppls/008222-00044-19690124.pdf. [Accessed November 18, 2019]

United States Environmental Protection Agency (USEPA) (1971) Lindane 25\% W-P (label). Available online: https:/www3.epa. gov/pesticides/chem_search/ppls/001990-00008-19710610.pdf. [Accessed November 18, 2019]

United States Environmental Protection Agency (USEPA) (1986) National Service Center for Environmental Publications (NSCEP). Pesticide fact sheet, name of chemical: Aldrin, reason for issuance: registration standard, date issued: December 1986, Fact Sheet Number: 108. Available online: https://nepis.epa.gov/Exe/ZyPDF. cgi/91024T4C.PDF?Dockey=91024T4C.PDF. [Accessed September 6, 2019]

United States Environmental Protection Agency (USEPA) (1995) Reregistration eligibility decision (RED): Fenitrothion. 222 pp. Available online: https://archive.epa.gov/pesticides/reregistration/ web/pdf/0445.pdf. [Accessed November 18, 2019]

United States Environmental Protection Agency (USEPA) (1998) Toxicology chapter for the methyl parathion RED. Case 0153, Chemical Code 05301, DP Barcode D243905. 22 pp. Available online: https://archive.epa.gov/pesticides/chemicalsearch/chemical/ foia/web/pdf/053501/053501-041.pdf. [Accessed November 12, 2019]

United States Environmental Protection Agency (USEPA) (1999). Final EFED RED Chapter for Methyl Parathion PC Code No. 053501.83 pp. Available online: https://archive.epa.gov/pesticides/ chemicalsearch/chemical/foia/web/pdf/053501/053501-048.pdf. [Accessed November 12, 2019]

United States Environmental Protection Agency (USEPA) (2002a) Federal Water Pollution Control Act [As Amended Through P.L. 107-303, November 27, 2002]. Available online: https://www.epa. gov/sites/production/files/2017-08/documents/federal-waterpollution-control-act-508full.pdf. [Accessed September 12, 2019]

United States Environmental Protection Agency (USEPA) (2002b) Reregistration eligibility decision for lindane. Case 315. September 25, 2002. Available online: https://www3.epa.gov/ pesticides/endanger/litstatus/effects/lindane/attach-1.pdf. [Accessed November 18, 2019]

United States Environmental Protection Agency (USEPA) (2003) Health effects support document for Aldrin/Dieldrin. Prepared for Office of Water, Health and Ecological Criteria Division. EPA 822-R-03-001. February 2003, 255 pp

United States Environmental Protection Agency (USEPA) (2006a) Interim Reregistration Eligibility Decision (IRED) Document for Dichlorvos (DDVP). July 31, 2006. 342 pp. Available online: 
https://archive.epa.gov/pesticides/reregistration/web/pdf/ddvp_ired. pdf. [Accessed November 18, 2019]

United States Environmental Protection Agency (USEPA) (2006b) Reregistration eligibility decision for phosmet. $136 \mathrm{pp}$. Available online: https://archive.epa.gov/pesticides/reregistration/web/pdf/ phosmet_red.pdf. [Accessed November 18, 2019]

United States Environmental Protection Agency (USEPA) (2006c) Interim reregistration eligibility decision for azinphos-methyl. Case No. 0235. 150 pp. Available online: https://archive.epa.gov/ pesticides/reregistration/web/pdf/azinphosmethyl_ired.pdf. [Accessed November 18, 2019]

United States Environmental Protection Agency (USEPA) (2008) Registration review-preliminary problem formulation for ecological risk and environmental fate, endangered species and drinking water assessments for diazinon (PC Code 057801; DP Barcode D349527). 43 pp.

United States Environmental Protection Agency (USEPA) (2009a) Registration review - preliminary problem formulation for ecological risk and environmental fate, endangered species and drinking water assessments for methyl parathion. April 20, 2009, PC Code 053501; DP Barcode 359339, 359340. Available online: https:// www.regulations.gov/document?D=EPA-HQ-OPP-2009-03320007. [Accessed September 6, 2019]

United States Environmental Protection Agency (USEPA) (2009b) Problem formulation for the environmental fate and ecological risk, endangered species, and drinking water assessments in support of the registration review of phosmet. April 16, 2009, PC Code 059201, DP Barcode D362665. Available online: https://www. regulations.gov/document?D=EPA-HQ-OPP-2009-0316-0003. [Accessed November 18, 2019]

United States Environmental Protection Agency (USEPA) (2010a) Fenitrothion. Risk assessment to support final registration review decision. November 10, 2010, PC Code 105901, DP Barcode D383647. Available online: https://www.regulations.gov/ document?D=EPA-HQ-OPP-2009-0172-0016. [Accessed November 22, 2019]

United States Environmental Protection Agency (USEPA) (2010b) EFED registration review problem formulation for bifenthrin. June 9, 2010, PC code 128825, DP barcode D370920. Available online: https://www.regulations.gov/document?D=EPA-HQ-OPP2010-0384-0006. Accessed 18 Nov 2019

United States Environmental Protection Agency (USEPA) (2010c) EFED registration review problem formulation for lambda-cyhalothrin and gamma-cyhalothrin. November 22, 2010, PC Codes 128897 and 128807. Available online: https://www.regulations.gov/document? D=EPA-HQ-OPP-2010-0480-0005 . Accessed 18 Nov 2019

United States Environmental Protection Agency (USEPA) (2011a) Chlorpyrifos: preliminary human health risk assessment for registration. June 30, 2011, PC Code 059101, DB Barcode D388070. Available online: https://www.regulations.gov/document?D= EPA-HQ-OPP-2008-0850-0025/ . Accessed 18 Nov 2019

United States Environmental Protection Agency (USEPA) (2011b) EFED registration review problem formulation for permethrin. June 20, 2011, PC Code 109701, DP Barcode D38703. Available online : https://www.regulations.gov/document?D=EPA-HQ-OPP2011-0039-0004 . Accessed 18 Nov 2019

United States Environmental Protection Agency (USEPA) (2012a) Problem formulation for the environmental fate and ecological risk, endangered species, and drinking water assessments in support of the registration review of racemic cypermethrin and zetacypermethrin. March 1, 2012, PC Code 109702, 129064, DP Barcode 395264. Available online: https://www.regulations.gov/ document?D=EPA-HQ-OPP-2012-0167-0003 . Accessed 18 Nov 2019

United States Environmental Protection Agency (USEPA) (2012b) Sulfoxaflor - new active ingredient human health risk assessment of uses on numerous crops. PC Code 005210, DP Barcode D382604, D382605, D382607. Available online: https://www. regulations.gov/document?D=EPA-HQ-OPP-2010-0889-0011. Accessed 18 Nov 2019

United States Environmental Protection Agency (USEPA) (2012c) Problem formulation for the environmental fate and ecological risk, endangered species, and drinking water assessments in support of the registration review of thiacloprid. PC Code 014019, DP Barcode 399796. August 9, 2012. Available online: https://www. regulations.gov/document?D=EPA-HQ-OPP-2012-0218-0010 . [Accessed November 12, 2019]

United States Environmental Protection Agency (USEPA) (2012d) Thiacloprid. Human health assessment scoping document in support of registration review. PC Code 014019, DP Barcode D399795. August 8, 2012. Available online: https://www.regulations.gov/ document?D=EPA-HQ-OPP-2012-0218-0003 . Accessed 12 Nov 2019

United States Environmental Protection Agency (USEPA) (2016a) Malathion. Human health draft risk assessment for registration review. PC code 057701. Available online: https://www3.epa.gov/ pesticides/Malathion-Human-Health-Draft-Risk-Assessment-forRegistration-Review.pdf. [Accessed September 16, 2019]

United States Environmental Protection Agency (USEPA) (2016b) Preliminary comparative environmental fate and ecological risk assessment for the registration review of eight synthetic pyrethroids and the pyrethrins. PC codes 069001,097805, 109303, 109701, 109702, 127901, 128825, 128831, 128897, and 118831, 128807, 129064,209600, DP barcode D425791, D429461, D433338, D433339 and D435888. Available online: https://www. regulations.gov/document?D=EPA-HQ-OPP-2011-0039-0040. [Accessed September 9, 2019]

United States Environmental Protection Agency (USEPA) (2016c) Cypermethrin. Aerobic soil metabolism of [14C]cypermethrin in three soils. Final report. MRID 49743601, PC Code 109702. Available online: https://www.regulations.gov/document?D=EPAHQ-OPP-2012-0167-0041. Accessed 9 Sept 2019

United States Environmental Protection Agency (USEPA) (2016d) Fenpropathrin. Draft human health risk assessment for registration review. PC Code 127901, DP Barcode D425768. May 18, 2016. Available online: https://www.regulations.gov/document?D=EPAHQ-OPP-2010-0422-0017 . [Accessed September 9, 2019]

United States Environmental Protection Agency (USEPA) (2016e) Preliminary pollinator assessment to support the registration review of imidacloprid. PC code: 129099. Available online: https://www. regulations.gov/document?D=EPA-HQ-OPP-2008-0844-0140. [Accessed September 9, 2019]

United States Environmental Protection Agency (USEPA) (2017a) Bifenthrin occupational and residential exposure and risk assessment for registration review and to evaluate the proposed uses of bifenthrin PC code 128825. pp. 96

United States Environmental Protection Agency (USEPA) (2017b) Permethrin. Human health draft risk assessment for registration review. June 30, 2017, PC Code 109701, DP Barcode D414137. Available online: https://www.regulations.gov/document?D= EPA-HQ-OPP-2011-0039-0088 . [Accessed September 9, 2019]

United States Environmental Protection Agency (USEPA) (2017c) Deltamethrin. Draft human health risk assessment for registration review. PC Code 097805, DP Barcode D420609. June 5, 2017. 74 pp. Available online: https://www.regulations.gov/document?D= EPA-HQ-OPP-2009-0637-0036 . Accessed 9 Sept 2019

United States Environmental Protection Agency (USEPA) (2017d) Cyfluthrin and beta-cyfluthrin. Draft human health risk assessment for registration review. PC Code 128831, 118831, DP Barcode D433405. September 1, 2017. Available online: https://www. regulations.gov/document?D=EPA-HQ-OPP-2010-0684-0102 . Accessed 9 Sept 2019 
United States Environmental Protection Agency (USEPA) (2017e) Esfenvalerate. Draft human health risk assessment for registration review. PC Code 109303, DP Barcode 414149. March 31, 2017. Available online: https://www.regulations.gov/document?D=EPAHQ-OPP-2009-0301-0074. Accessed 9 Sept 2019

United States Environmental Protection Agency (USEPA) (2017f) Thiamethoxam-transmittal of the preliminary aquatic and nonpollinator terrestrial risk assessment to support registration review. PC code: 060109, DP barcode: 439307. Available online: https:// www.regulations.gov/document?D=EPA-HQ-OPP-2011-05810093. [Accessed September 9, 2019]

United States Environmental Protection Agency (USEPA) (2017g) Preliminary bee risk assessment to support the registration review of clothianidin and thiamethoxam. PC codes: 044309, 060109, DP barcode: 437097. Available online: https:/www.regulations.gov/ document?D=EPA-HQ-OPP-2011-0581-0034. [Accessed September 9, 2019]

United States Environmental Protection Agency (USEPA) (2017h) Imidacloprid-transmittal of the preliminary terrestrial risk assessment to support the registration review. PC Code: 129099, DP Barcode: 442930. Available online: https://www.regulations.gov/ document?D=EPA-HQ-OPP-2008-0844-1256. [Accessed September 9, 2019]

United States Environmental Protection Agency (USEPA) (2017i) Clothianidin-transmittal of the preliminary aquatic and nonpollinator terrestrial risk assessment to support registration review. PC code: 044309 , DP barcode: 439290. Available online: https:// www.regulations.gov/document?D=EPA-HQ-OPP-2011-08650242. [Accessed September 9, 2019]

United States Environmental Protection Agency (USEPA) (2017j) Preliminary ecological risk assessment (excluding terrestrial invertebrates) for the registration review of dinotefuran. PC code: 044312, DP barcode: 441527. Available online: https://www. regulations.gov/document?D=EPA-HQ-OPP-2011-0920-0616. [Accessed September 9, 2019]

United States Environmental Protection Agency (USEPA) (2017k) Draft assessment of the potential effects of dinotefuran on bees. DP Barcode: 437374, PC Code: 044312. Available online: https:// www.regulations.gov/document?D=EPA-HQ-OPP-2011-09200014. [Accessed September 9, 2019]

United States Environmental Protection Agency (USEPA) (20171) Preliminary environmental fate and ecological risk assessment in support of the registration of acetamiprid. PC Code 099050, DP Barcode 441940. Available online: https://www.regulations.gov/ document?D=EPA-HQ-OPP-2012-0329-0026. [Accessed November 18, 2019]

United States Environmental Protection Agency (USEPA) (2017m) Acetamiprid. Draft human health risk assessment for registration review. PC Code 099050, DP Barcode D441937, D441938. December 15, 2017. Available online: https://www.regulations. gov/document?D=EPA-HQ-OPP-2012-0329-0025 . Accessed 18 Nov 2019

United States Environmental Protection Agency (USEPA) (2018a) Label review manual. Chapter 7: precautionary statements. Available online: https://www.epa.gov/pesticide-registration/label-reviewmanual. [Accessed August 28, 2019]

United States Environmental Protection Agency (USEPA) (2018b) Chlorpyrifos draft biological evaluation. Available online: https:// www.epa.gov/endangered-species/biological-evaluation-chapterschlorpyrifos-esa-assessment. Accessed 18 Nov 2019

United States Environmental Protection Agency (USEPA) (2018c) Malathion draft biological evaluation. Available online: https:// www.epa.gov/endangered-species/biological-evaluation-chaptersmalathion-esa-assessment . [Accessed November 18, 2019]

United States Environmental Protection Agency (USEPA) (2018d) Diazinon draft biological evaluation. Available online: https:// www.epa.gov/endangered-species/biological-evaluation-chaptersdiazinon-esa-assessment . Accessed 18 Nov 2019

United States Environmental Protection Agency (USEPA) (2019) Sulfoxaflor: ecological risk assessment for Section 3 registration for various proposed new uses. PC Code: 005210, DP Barcode 449891. July 10, 2019. Available online: https://www.regulations. gov/document?D=EPA-HQ-OPP-2010-0889-0566 . [Accessed November 18, 2019]

United States Fish and Wildlife Service (USFWS) (1973) Endangered Species Act of 1973 (16 U.S.C. 1531-1544, 87 Stat. 884), as amended - Public Law 93-205, approved December 28, 1973, repealed the Endangered Species Conservation Act of December 5, 1969 (P.L. 91-135, 83 Stat. 275). Department of the Interior, U.S. Fish and Wildlife Service, Washington, D.C. 20240. https:// www.fws.gov/endangered/esa-library/pdf/ESAall.pdf

United States Fish and Wildlife Service (USFWS) (2016) Table 1: causes of mortality in wild red wolves (Canis rufus) 2013-2016. https:// www.fws.gov/redwolf/Images/Mortalitytable.pdf . Accessed 9 Sept 2019

United States Fish and Wildlife Service (USFWS) (2017) Sage-grouse, sagebrush and the threat posed by invasive annual grasses/increased fire frequency. Available online: https://www.fws.gov/mountainprairie/factsheets/Inv_Fire_101813.pdf. Accessed 9 Sept 2019

Vitousek PM, D'antonio CM, Loope LL, Rejmanek M, Westbrooks R (1997) Introduced species: a significant component of humancaused global change. N Z J Ecol 21(1):1-6

Washington Post (2015) The dirty dozen: 12 of the most destructive invasive animals in the United States. February 23, 2015. Available online: https://www.washingtonpost.com/news/energyenvironment/wp/2015/02/23/like-most-invasive-species-pythonsare-in-the-u-s-to-stay/ Accessed 9 Sept 2019

Wolfersberger J, Delacote P, Garcia S (2015) An empirical analysis of forest transition and land-use change in developing countries. Ecol Econ 119:241-251

World Health Organization (WHO) (1989) DDT and its derivatives. Environmental aspects. Environmental Health Criteria. Geneva, Switzerland, Vol. 83. ISBN 924154283 7. Available online: http://www.inchem.org/documents/ehc/ehc/ehc83.htm. [Accessed September 9, 2019]

World Health Organization (WHO) (2006) Heptachlor. Concise International Chemical Assessment Document 70. First draft prepared by J. Kielhorn, S. Schmidt, and I. Mangelsdorf. 84 pp.

World Health Organization (WHO) (2015) WHO specifications and evaluations for public health pesticides. Chlorpyrifos. $53 \mathrm{pp}$.

World Health Organization (WHO) (2017) WHO specifications and evaluations for public health pesticides. Bifenthrin. $61 \mathrm{pp}$. Available online: https://www.who.int/whopes/quality/Bifenthrin_WHO specs_eval_March_2017.pdf?ua=1\&ua=1. [Accessed November 12, 2019]

WWF (2018) Living Planet Report - 2018: aiming higher. Grooten, M. and Almond, R.E.A.(Eds). WWF, Gland, Switzerland. 148 pp.

Zalles V, Hansen MC, Potapov PV, Stehman SV, Tyukavina A, Pickens A, Zong X-P, Adusei B, Okpa C, Aguilar R, John N, Chavez S (2019) Near doubling of Brazil's intensive row crop area since 2000. Proc Natl Acad Sci 11116(2):428-435

Zax D (2007) A brief history of house cats. Smithsonian magazine. Available online: https://www.smithsonianmag.com/history/abrief-history-of-house-cats-158390681 . Accessed 10 Sept 2019

Zhai D, Xu J, Dai Z, Schmidt-Vogt D (2017) Lost in transition: forest transition and natural forest loss in tropical China. Plant Diversity 39(3):149-153

Publisher's note Springer Nature remains neutral with regard to jurisdictional claims in published maps and institutional affiliations. 